\title{
Individual growth model for the appendicularian Oikopleura dioica
}

\author{
Franck Touratier $^{1, *}$, François Carlotti ${ }^{2}$, Gabriel Gorsky ${ }^{3}$ \\ ${ }^{1}$ Université de Perpignan, 52, avenue de Villeneuve, 66860 Perpignan, France \\ ${ }^{2}$ Université Bordeaux 1, UMR 5805, Laboratoire d'Océanographie Biologique, Station Marine d'Arcachon, \\ 2, rue du Professeur Jolyet, 33120 Arcachon, France \\ ${ }^{3}$ LOV, UMR 9073, Station Zoologique, Observatoire Océanologique, BP 28, 06234 Villefranche sur Mer, France
}

\begin{abstract}
A model of individual growth simulating the development of the main compartments and processes involved in the ecophysiology of the appendicularian Oikopleura dioica is presented. $O$. dioica is one of the 5 most frequent larvacean species inhabiting European seas, and laboratory studies are available for comparison with model outputs. Individual growth and interactions with the external medium are described by state variables and fluxes of $\mathrm{C}$ and $\mathrm{N}$, using the stoichiometric approach. Three forcing variables control the animal's growth: temperature, food quantity, and food quality (i.e. C:N ratio and size of particles). Model outputs are compared to experimental data to analyse (1) the effect of food quantity and quality on trunk length; (2) the influence of temperature on trunk length, generation time, respiration, excretion and house production rate; (3) the variability of the filtration rate under different conditions of temperature, food quantity and food quality. Results of the model are coherent with most observations, and validation of the model was successful.
\end{abstract}

KEY WORDS: Appendicularia $\cdot$ Ecophysiology $\cdot$ Modelling $\cdot$ Carbon $\cdot$ Nitrogen

\section{INTRODUCTION}

Appendicularians are thought to play an important role in the flux of material throughout the water column. This recent view emerges from the following characteristics: (1) most appendicularian species are capable of high grazing rates on a wide spectrum of particles, including microbial phytoplankton, bacteria and small detritus, and they are also able to utilise dissolved organic matter (DOM) (Nakamura et al. 1997, Gorsky \& Fenaux 1998, Gorsky et al. 1999); (2) their growth rates may be very high in situ ( $>10$ up to $23 \mathrm{~d}^{-1}$; Hopcroft \& Roff 1995), i.e. 1 order of magnitude greater than those of copepods of equivalent body size; (3) appendicularians may outcompete copepods in regenerative and microbial food web-based systems (Deibel 1998, Gorsky et al. 1999); (4) they could significantly increase and accelerate the export of carbon and associated elements (abandoned houses, fecal pellets, cadavers, and detritus (e.g. Alldredge 1976, Gorsky et

*Email: touratie@univ-perp.fr al. 1984, López-Urrutia \& Acuña 1999); (5) dense populations of pelagic tunicates may deplete available food in a few days (Alldredge 1981, Deibel 1985); and (6) pelagic tunicates represent a single-step shunt between their small prey and their potential predators (chaetognaths, medusae, ctenophores, and fishes; e.g. Azam et al. 1983, Fortier et al. 1994, Gorsky \& Fenaux 1998).

The overall objective of the EURAPP program (EURopean APPendicularians: www.obs-vlfr.fr/ eurapp/) was to improve our knowledge about the ecological role of distinct appendicularian species in representative marginal seas of Europe, in relation to the flux of colloidal and particulate organic matter, and in relation to the structure, dynamics and resilience of important components in the marine plankton community as a whole.

The specific objectives of the present paper are to (1) describe the functioning of 1 appendicularian species at the organism level in controlled conditions; (2) build an individual growth model to simulate the 
a)

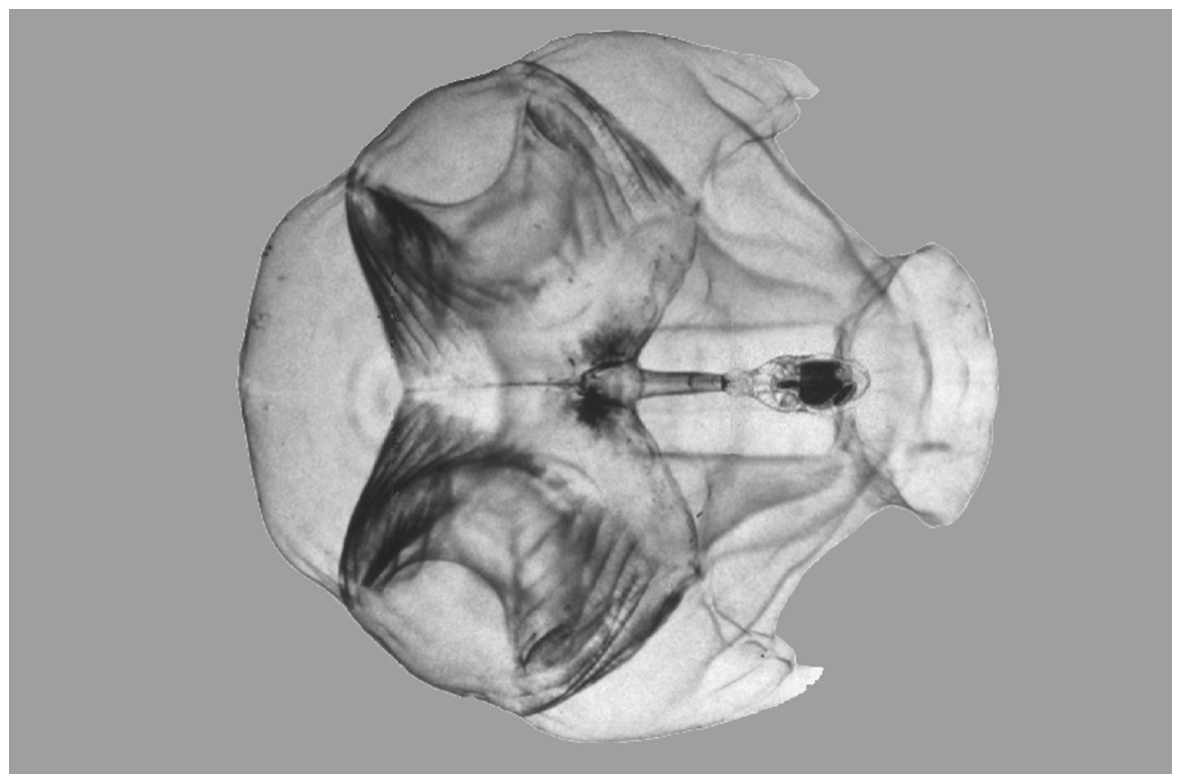

b)

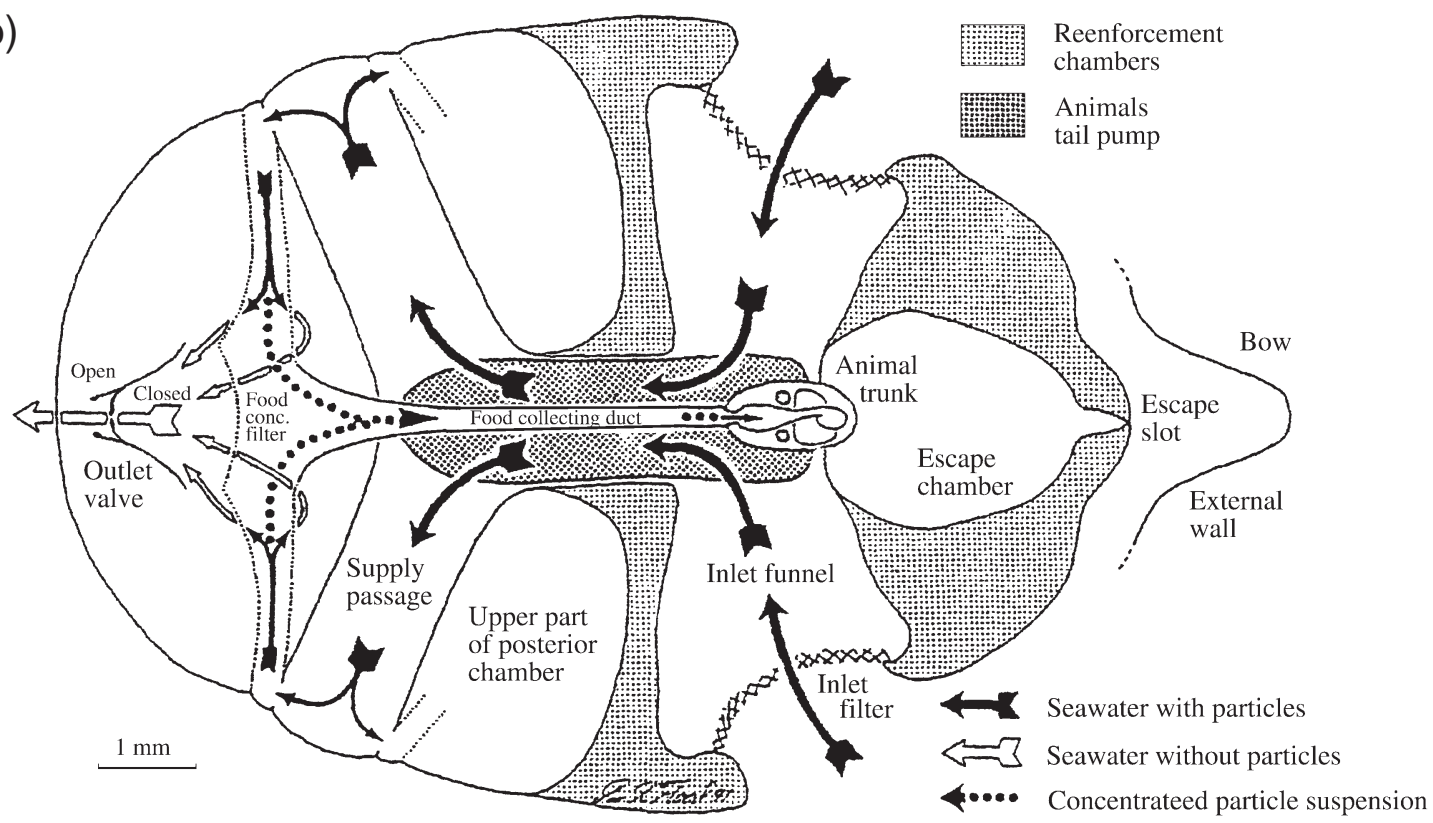

Fig. 1. (a) Oikopleura dioica (Fol 1872) inside its house (photograph by R. Fenaux; www.obs-vlfr.fr/ eurapp/). (b) Oikopleura labradoriensis. Diagram showing the internal structure and seawater circulation in the house; black arrows indicate water flow through the house before, and white arrows after its passage through the food concentrating filter. The flow of trapped particles towards the mouth of the animal is indicated by the dotted arrows (after Flood \& Deibel 1998)

evolution of compartments and processes involved in the ecophysiology of the individual; and (3) study the role of the individual in the transformation of elements and organic matter.

The species Oikopleura doica (Fol, 1872; Fig. 1a) was selected for 2 reasons; (1) it is one of the 5 most representative species found in the European seas (Fenaux 1961, Acuña \& Anadón 1992, Acuña et al. 1995), (2) it is one of the best known appendicularian species from both in situ and laboratory studies. Given the possibility to maintain successive generations of this species in the laboratory (Fenaux \& Gorsky 1985, Gorsky et al. 1987), experimental results are now available to build, calibrate and validate an individual growth model for this species.

Details concerning the internal structure of the oikopleurid house (Fig. 1b) and its functioning can be found in Flood \& Deibel (1998) and references therein. 
Oikopleura dioica uses its house to filter and concentrate food particles from the surrounding water. Undulating tail movements cause seawater to circulate through the house. During the feeding process ciliated spiracles on the floor of the pharyngeal cavity create the inflowing current that facilitates the introduction of food items into the pharynx (Gorsky 1980, Deibel \& Powell 1987, Acuña et al. 1996). Before reaching the stomach, food particles undergo 3 different filtering processes. Large particles are excluded by the inlet filters, the digestible size particles are concentrated by the food-concentrating filter and are transported to the stomach by the pharyngeal filter. The inlet filter pore size of $O$. dioica is ca. $18 \mu \mathrm{m}$ with a maximum observed between 20 and $25 \mu \mathrm{m}$ (Galt 1972, Deibel \& Turner 1985, Flood \& Deibel 1998). These filters, which are subject to clogging (the house must be abandoned in this case; Deibel \& Lee 1992, Acuña et al. 1999), prevent large and potentially harmful particles from entering the house. The pore size of the food-concentrating filter is much smaller $(0.150 .98 \mu \mathrm{m}$; Flood 1981), and this system is designed to concentrate the particles several hundredfold (Morris \& Deibel 1993). Collected particles are then drained into the pharynx via the food collecting tube (Fig. 1b). Before being ingested, particles must be captured by the pharyngeal filter which is continuously secreted by the endostyle. Surprisingly, the pore size of this filter was observed to be larger than that of the foodconcentrating filter in O. vanhoeffeni (Acuña et al. 1996). However, according to the latter authors, particles smaller than the pharyngeal filter pore size could be retained not only by direct interception, but also by diffusional deposition.

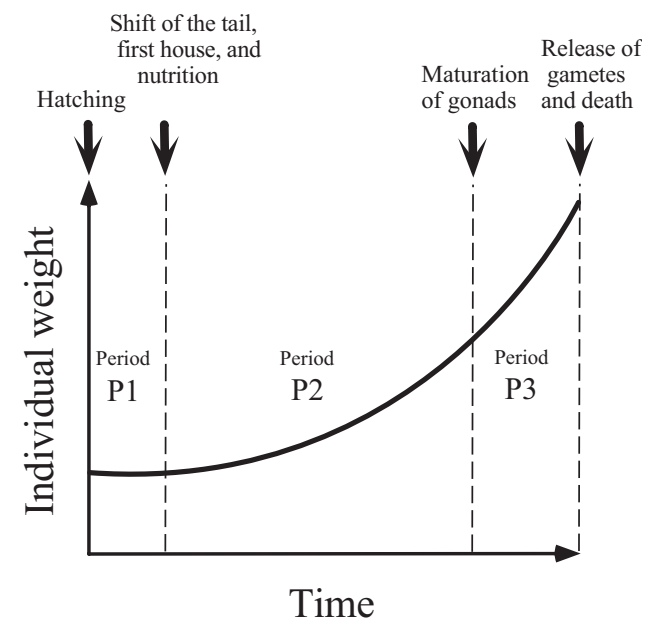

Fig. 2. Oikopleura dioica. Overview of growth and of the development periods (P1 to P3) modelled, which are delimited by 4 events: hatching, shift of the tail, maturation of gonads, and release of gametes
The size of particles that are potentially ingested by Oikopleura dioica ranges from 0.1 to approximately $25 \mu \mathrm{m}$ (e.g. Flood 1978, Fenaux 1986), and the retention efficiency generally exceeds $90 \%$ for particles >3 $\mu \mathrm{m}$ (Deibel \& Lee 1992, Gorsky et al. 1999). Dissolved organic matter (DOM), bacteria, flagellates, pico- and nano-phytoplankton, amorphous particles (Alldredge 1981, Flood et al. 1992) are all potential food items for these animals which filter non-selectively (e.g. Gorsky 1980, Deibel \& Turner 1985, Bedo et al. 1993). O. dioica individuals pump seawater continuously, except when a new house is deployed (Deibel 1988, Gorsky \& Palazzoli 1989), and they do not show any evidence of a diel feeding rhythm (Alldredge 1981).

\section{METHODS}

\section{Overview of the Oikopleura dioica life cycle}

The life cycle of appendicularians is simple compared to other zooplankton organisms such as copepods or other gelatinous organisms. Small differences among species exist, but the overall sequence of the life cycle remains the same. The simplicity and similarity of appendicularian life histories are advantageous when modelling their individual growth, population dynamics, and competition for resources.

Details concerning the life cycle of the genus Oikopleura can be found in Galt (1972), Fenaux (1976, 1998b), Paffenhöfer (1976), and Fenaux \& Gorsky (1983). O. dioica is dioecious, in contrast to all other appendicularians, which are hermaphrodite. According to Fenaux (1976), its life cycle is marked by 3 periods separated by 4 significant events: fertilization, hatching, shift of the tail, and release of gametes. For this modelling study we consider, however, that the life of an individual is marked by hatching, shift of the tail, maturation of gonads and release of gametes (Fig. 2). Fertilization is not considered since we do not intend to model the population dynamics. The event termed 'maturation of gonads' corresponds to the period in the life cycle after which most of the available resources will be allocated to gametogenesis.

During Period P1, the trunk and the tail of the individual develop progressively; the individual is not able to filter seawater and consequently cannot ingest food particles. Its growth is negative, but the loss in weight is very small (Fenaux \& Gorsky 1983). This period is also characterized by construction of the first house rudiment around the trunk. The mucus of this rudiment is secreted by the oikoplastic epithelium that occupies a large area (the oikoplastic region) above the mouth of the animal. 
The shift of the tail is an important event in the life cycle, after which the pre-built house rudiment is deployed around the animal. The house is then used to filter seawater and concentrate particles prior to their ingestion. In the model, the duration of house deployment is considered to be insignificant, which is a reasonable approximation given the fact that it takes only a few dozen seconds (Fenaux 1985, Gorsky \& Palazzoli 1989). At the beginning of Period $P 2$, the somatic cells reach their definitive number. The animal will thereafter gain additional weight by increasing the volume of these polyploïd cells, and by investing new materials into the construction of gonads and production of gametes.

Development of the gonads accelerates during Period P3. Maturation of the reproductive cells is a priority, since autolysis phenomena of oikoplastic and digestive cells have been observed at this stage. Autolysed material is apparently re-invested into the gonads (Gorsky 1980, Fenaux \& Gorsky 1983). When gonads are mature, house rudiment secretion ceases since most oikoplastic cells are autolysed. The last house is abandoned just before the release of reproductive cells, a strategy that favours the dispersion of gametes. The sperm of male individuals is released through a spermiduct, whereas the oocytes of females are released by rupture of the ovary and genital cavity walls (Fenaux 1998a). In all cases, the death of animals occurs shortly after this event.
To survive during $\mathrm{P} 1$ and maximize reproductive potential at the end of P3, Periods P1 and P3 should be very short. In cultures of Oikopleura longicauda at $20^{\circ} \mathrm{C}$, Fenaux \& Gorsky (1983) showed that Periods P1, P2, and P3 last approximately 0.5, 6.16, and $1 \mathrm{~d}$, respectively.

The symbols, descriptions and units of the 18 state variables of the present model are shown in Table 1, and information relative to the model parameters is given in Table 2. The model is built using several principles of the stoichiometric approach (see e.g. Sterner 1990, Touratier et al. 1999, 2001), which combines at least 2 elemental units (carbon and nitrogen in the present study) to compute variables and flows. The main advantage of this multi-currency approach is that both food quantity and food quality ( $\mathrm{C}: \mathrm{N}$ ratio) influence the computation of the most important processes in the model.

Whatever the period considered thereafter, all $\mathrm{C}$ and $\mathrm{N}$, continuous or discrete flows linking the state variables of the model are represented in the connectivity matrix (Table 3).

\section{Modelling Period P1}

During Period P1, the animal must survive without feeding and build the first house rudiment from its own reserves. The state variables and processes used to

Table 1. Variables of the growth model of Oikopleura dioica. Units are in $\mu \mathrm{g} x$ ind.$^{-1}$ bottle $^{-1}$ ( $x$ stands for C or N)

\begin{tabular}{|c|c|c|}
\hline Symbols & Descriptions & Elemental unit $x$ \\
\hline $\mathrm{D}_{\mathrm{C}}$ & Carbon weight of detritus accumulated on the inner wall of the working house & $\mathrm{C}$ \\
\hline $\mathrm{D}_{\mathrm{N}}$ & Nitrogen weight of detritus accumulated on the inner wall of the working house & $\mathrm{N}$ \\
\hline $\mathrm{E}_{\mathrm{C}}$ & Carbon weight of the gametes & $\mathrm{C}$ \\
\hline $\mathrm{E}_{\mathrm{N}}^{\mathrm{a}}$ & Nitrogen weight of the gametes & $\mathrm{N}$ \\
\hline $\mathrm{F}_{\mathrm{C}}$ & Carbon weight of the food outside the house & $\mathrm{C}$ \\
\hline $\mathrm{F}_{\mathrm{N}}$ & Nitrogen weight of the food outside the house & $\mathrm{N}$ \\
\hline $\mathrm{FP}_{\mathrm{C}}$ & Carbon weight of fecal pellets accumulated in the medium & $\mathrm{C}$ \\
\hline $\mathrm{FP}_{\mathrm{N}}$ & Nitrogen weight of fecal pellets accumulated in the medium & $\mathrm{N}$ \\
\hline $\mathrm{G}_{\mathrm{C}}$ & Carbon weight of the gonads & $\mathrm{C}$ \\
\hline $\mathrm{G}_{\mathrm{N}}^{\mathrm{a}}$ & Nitrogen weight of the gonads & $\mathrm{N}$ \\
\hline $\mathrm{H}_{\mathrm{C}}$ & Carbon weight of the working house & $\mathrm{C}$ \\
\hline $\mathrm{H}_{\mathrm{N}}{ }^{\mathrm{a}}$ & Nitrogen weight of the working house & $\mathrm{N}$ \\
\hline $\mathrm{HF}_{\mathrm{C}}$ & Carbon weight of the food inside the house & $\mathrm{C}$ \\
\hline $\mathrm{HF}_{\mathrm{N}}$ & Nitrogen weight of the food inside the house & $\mathrm{N}$ \\
\hline $\mathrm{HR}_{\mathrm{C}}$ & Carbon weight of house rudiment & $\mathrm{C}$ \\
\hline $\mathrm{HR}_{\mathrm{N}}{ }^{\mathrm{a}}$ & Nitrogen weight of house rudiment & $\mathrm{N}$ \\
\hline $\mathrm{OD}_{\mathrm{C}}$ & Carbon weight of detritus accumulated on the inner wall of old houses & $\mathrm{C}$ \\
\hline $\mathrm{OD}_{\mathrm{N}}$ & Nitrogen weight of detritus accumulated on the inner wall of old houses & $\mathrm{N}$ \\
\hline $\mathrm{OH}_{\mathrm{C}}$ & Carbon weight of old houses & $\mathrm{C}$ \\
\hline $\mathrm{OH}_{\mathrm{N}}{ }^{\mathrm{a}}$ & Nitrogen weight of old houses & $\mathrm{N}$ \\
\hline $\mathrm{R}_{\mathrm{C}}$ & Carbon weight of respired products & $\mathrm{C}$ \\
\hline $\mathrm{R}_{\mathrm{N}}$ & Nitrogen weight of excreted products & $\mathrm{N}$ \\
\hline $\mathrm{SB}_{\mathrm{C}}$ & Carbon weight of structural biomass without the gonads & $\mathrm{C}$ \\
\hline $\mathrm{SB}_{\mathrm{N}}^{\mathrm{a}}$ & Nitrogen weight of structural biomass without the gonads & $\mathrm{N}$ \\
\hline
\end{tabular}


Table 2. Oikopleura dioica. Growth model parameters. Wd: without dimension

\begin{tabular}{|c|c|c|c|}
\hline Description & Symbols & Values & Units \\
\hline Coefficient of the allometric equation for food intake at $0^{\circ} \mathrm{C}$ & a & $52.54^{\mathrm{a}}$ & $\operatorname{pgC}^{0.25} \mathrm{~d}^{-1}$ \\
\hline Carbon assimilation coefficient & ac & $0.67^{b}$ & $\mathrm{Wd}$ \\
\hline Nitrogen assimilation coefficient & an & $0.72^{\mathrm{b}}$ & $\mathrm{Wd}$ \\
\hline Slope of the regression line between trunk length and temperature & atl & $-50^{\mathrm{c}}$ & $\mu \mathrm{m}\left({ }^{\circ} \mathrm{C}\right)^{-1}$ \\
\hline Exponent of the allometric equation for food intake & $\mathrm{b}$ & $-0.25^{\mathrm{d}}$ & $\mathrm{Wd}$ \\
\hline Gonad construction rate from structural biomass at $0^{\circ} \mathrm{C}$ during $\mathrm{P} 3$ & $\operatorname{cg} 3$ & 0.02 & $d^{-1}$ \\
\hline House rudiment construction rate at $0^{\circ} \mathrm{C}$ during $\mathrm{P} 1$ & chr1 & 0.15 & $\mathrm{~d}^{-1}$ \\
\hline $\mathrm{C}: \mathrm{N}$ ratio for the structural biomass, the gonads, and the gametes & $\mathrm{cnb}$ & $5.3^{\mathrm{e}}$ & $\mu g C(\mu g N)^{-1}$ \\
\hline C:N ratio for the house rudiment, the working and the old houses & $\mathrm{cnh}$ & $250^{\mathrm{f}}$ & $\mu g C(\mu g N)^{-1}$ \\
\hline Fraction of food intake available for ingestion & ffi & 0.95 & $\mathrm{Wd}$ \\
\hline Fraction of fecal pellet production released in the medium & ffp & 0.95 & Wd \\
\hline Fraction of biomass production available for construction of the gonads during P2 & fg2 & 0.1 & Wd \\
\hline Fraction of biomass production available for construction of the house rudiment & fhr & 0.65 & Wd \\
\hline $\begin{array}{l}\text { Fraction of biomass production available for construction of the structural biomass } \\
\text { during P2 }\end{array}$ & fsb2 & 0.25 & Wd \\
\hline Fraction of the house volume unoccupied by the organism & $\mathrm{fv}$ & $0.66^{\mathrm{g}}$ & $\mathrm{Wd}$ \\
\hline Maximum net growth efficiency when assimilated food C: $\mathrm{N}$ ratio is equal to $\mathrm{cnb}$ & $\mathrm{k} 2 \mathrm{~m}$ & $0.44^{\mathrm{h}}$ & $\mathrm{Wd}$ \\
\hline $\begin{array}{l}\text { Half-saturation constant for the relationship representing the effect of forcing } E \\
\text { on ingestion }\end{array}$ & ke & 10000 & $\mu g C l^{-1}$ \\
\hline Half-saturation constant for food intake & $\mathrm{ki}$ & $240^{\mathrm{i}}$ & $\mu g C 1^{-1}$ \\
\hline Half-saturation constant for curve K2 & $\mathrm{kk} 2$ & 1 & $\begin{array}{l}\mu g C \text { ind. } \\
\text { bottle }^{-1} \mathrm{~d}^{-1}\end{array}$ \\
\hline Respiration rate at $0^{\circ} \mathrm{C}$ during $\mathrm{P} 1$ & res1 & 0.005 & $d^{-1}$ \\
\hline Size ratio between house diameter and trunk length & $\mathrm{rl}$ & $3.846^{\mathrm{j}}$ & Wd \\
\hline 10th root of $Q_{10}$ coefficient & $\mathrm{t} 10$ & $1.1084^{\mathrm{c}}$ & $\mathrm{Wd}$ \\
\hline Food concentration threshold for maintenance & $\mathrm{tf}$ & 1 & $\mu g C 1^{-1}$ \\
\hline Threshold for deployment of a new house (fraction of the sum $\mathrm{SB}_{C}+\mathrm{G}_{\mathrm{C}}$ ) & th & $0.2376^{\mathrm{c}}$ & Wd \\
\hline Maximum trunk length at $23^{\circ} \mathrm{C}$ & $\operatorname{tlm}$ & $740^{\mathrm{c}}$ & $\mu \mathrm{m}$ \\
\hline Threshold to enter period P3 (fraction of the maximum trunk length) & $\mathrm{ttl}$ & 0.8 & Wd \\
\hline
\end{tabular}

Table 3. Oikopleura dioica. Model connectivity matrix for all carbon and nitrogen flows (in $\mu \mathrm{g} x$ ind..$^{-1}$ bottle $^{-1} \mathrm{~d}^{-1}$, where $x$ stands for $\mathrm{C}$ or $\mathrm{N}_{i} \bullet$ : continuous flows, $\mathbf{\Delta}$ : discrete flows). Flows are defined as follows: $[\mathrm{D} \rightarrow \mathrm{OD}]_{X}$ : detritus rejection; $[\mathrm{F} \rightarrow \mathrm{HF}]_{X}$ : food intake; $[\mathrm{F} \rightarrow \mathrm{D}]_{X}$ : accumulation of food on the inner wall of the house; $[\mathrm{G} \rightarrow \mathrm{E}]_{\mathrm{X}}$ : release of gametes; $[\mathrm{H} \rightarrow \mathrm{OH}]_{X}$ : house rejection; $[\mathrm{HF} \rightarrow \mathrm{FP}]_{X}$ : production of fecal pellets; $[\mathrm{HF} \rightarrow \mathrm{SB}]_{x}$ : construction of structural biomass; $[\mathrm{HF} \rightarrow \mathrm{G}]_{X}$ : construction of gonads from food; $[\mathrm{HF} \rightarrow \mathrm{R}]_{x}$ : respiration/ excretion from food; $[\mathrm{HF} \rightarrow \mathrm{HR}]_{x}$ : construction of house rudiment from food; $[\mathrm{HF} \rightarrow \mathrm{D}]_{x}$ : accumulation of fecal pellets on the inner wall of the house; $[\mathrm{HR} \rightarrow \mathrm{H}]_{X}$ : deployment of the house rudiment; $[\mathrm{SB} \rightarrow \mathrm{G}]_{\mathrm{x}}$ : construction of gonads from structural biomass; $[\mathrm{SB} \rightarrow \mathrm{R}]_{X}$ : respiration/excretion from structural biomass; $[\mathrm{SB} \rightarrow \mathrm{HR}]_{X}$ : construction of house rudiment from structural biomass; $[\mathrm{G} \rightarrow \mathrm{R}]_{x}$ : respiration/excretion from gonads

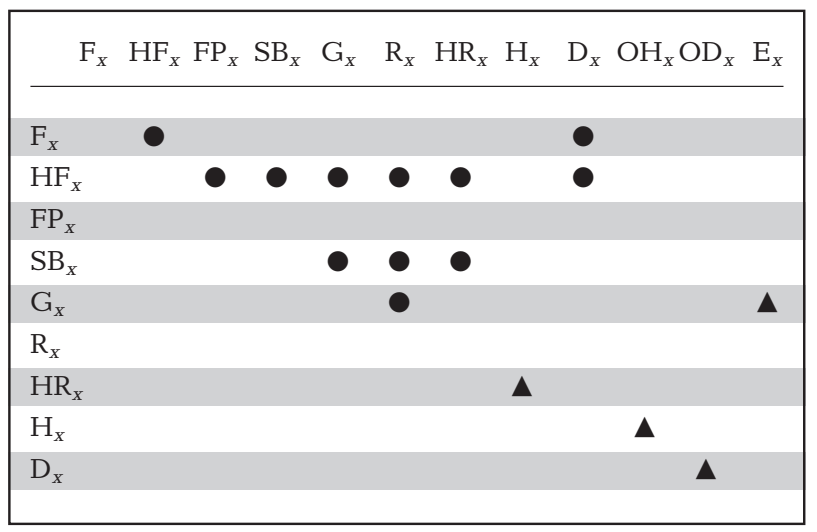




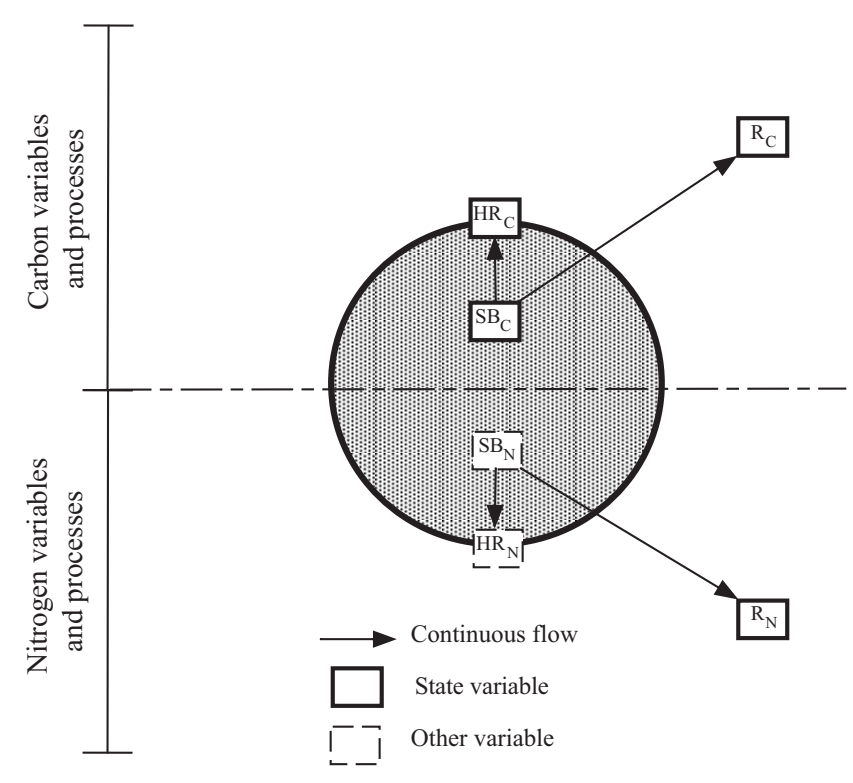

Fig. 3. Oikopleura dioica. Variables and processes used to model Period P1 of the life cycle. Symbols and units are described in Tables 1-3

simulate this period are shown in Fig. 3. Just after hatching, the carbon weight of the animal $\left(\mathrm{SB}_{\mathrm{C}}\right.$, see Table 1) is initialised to that of the egg, whereas all other state variables in the model (Table 1 ) are set to zero. The carbon weight of the egg $(0.013 \mu \mathrm{gC})$ is estimated assuming a diameter of $100 \mu \mathrm{m}$ (range: 60 to $107 \mu m_{i}$ Fenaux et al. 1986, Hopcroft \& Roff 1995, Fenaux 1998b), and we then use the carbon weight-trunk length relationship provided by King et al. (1980) for Oikopleura dioica: $\log _{10}$ (weight, $\left.\mu g C\right)=$ $2.6270 \log _{10}$ (trunk length, $\left.\mu \mathrm{m}\right)-7.1348$.

We assume that the hypothesis of strict homeostasis is valid for appendicularians (i.e. their elemental composition remains constant despite variable quality of the ingested food), as it has been shown to be the case in many other zooplankton groups such as copepods and cladocerans (see Touratier et al. 1999, 2001 and references therein). This assumption, which is partly justified by the absence of lipid storage in oikopleurids (Gorsky \& Palazzoli 1989, Deibel et al. 1992), considerably reduces the number of state variables and highlights the structure of the present model. For instance, during Period P1 (see Fig. 3), variables $\mathrm{SB}_{\mathrm{N}}$ and $\mathrm{HR}_{\mathrm{N}}$ (Table 1) are not state variables since we assume that ratios $\mathrm{SB}_{\mathrm{C}}: \mathrm{SB}_{\mathrm{N}}$ and $\mathrm{HR}_{\mathrm{C}}: \mathrm{HR}_{\mathrm{N}}$ remain constant. These 2 ratios are parameters $\mathrm{cnb}$ and $\mathrm{cnh}$ in the model, respectively (Table 2). The value $\mathrm{cnb}=5.3 \mu \mathrm{gC}$ $\mu \mathrm{gN}^{-1}$ was measured by Gorsky et al. (1988) for Oikopleura dioica and does not differ much from that of other zooplankton groups such as copepods and euphausiids. Houses of appendicularians are primarily composed of mucopolysaccharides (Körner 1952) with a very small nitrogen content relative to the carbon (Alldredge 1976). This means that parameter $\mathrm{cnh}$ is expected to be much higher than cnb. Alldredge (1976) determined the C:N ratio of 12 houses newly secreted by $O$. rufescens, and she found a mean value for $\mathrm{cnh}$ of $250 \mu \mathrm{gC} \mathrm{ggN}^{-1}$, which we use in the present study (Table 2). The large difference between $\mathrm{cnb}$ and $\mathrm{cnh}$ prevents the utilisation of a single $\mathrm{C}: \mathrm{N}$ ratio for the entire animal, as it is usually done when modelling other zooplankton groups. To describe the nitrogen compounds involved during Period P1, the state variable $\mathrm{R}_{\mathrm{N}}$ (Fig. 3, Table 1) is the quantity of excreted products (mostly ammonium; Gorsky 1980, Gorsky et al. 1987).

$\mathrm{C}$ and $\mathrm{N}$ flows during P1 are of 2 types (Fig. 3): construction of the house rudiment from structural biomass (symbolized by $[\mathrm{SB} \rightarrow \mathrm{HR}]_{x}$ ), and respiration or excretion (i.e. $[\mathrm{SB} \rightarrow \mathrm{R}]_{x}$ ), where the subscript $x$ stands for $\mathrm{C}$ or $\mathrm{N}$ unit (Table 3). All flows during P1 are continuous (Table 3 ) and their parameterisation is shown in Table 4. Respiration $[\mathrm{SB} \rightarrow \mathrm{R}]_{\mathrm{C}}$ (see Eq. 1 in Table 4) during Period P1 depends on the ambient temperature (T), following a $Q_{10}$ of 3.51 (Gorsky 1980) of which the 10th root is computed (parameter t10 in Table 2). The construction of the house rudiment in carbon or $[\mathrm{SB} \rightarrow \mathrm{HR}]_{\mathrm{C}}$ (see Eq. 2, Table 4) follows similar rules of parameterisation. To ensure that the $\mathrm{C}: \mathrm{N}$ ratio of the house rudiment will be equal to $\mathrm{cnh}$, the nitrogen flow for construction of the house rudiment $[\mathrm{SB} \rightarrow \mathrm{HR}]_{\mathrm{N}}$ must be $[\mathrm{SB} \rightarrow \mathrm{HR}]_{\mathrm{C}}$ divided by cnh (Eq. 4 in Table 4 ). Ammonium excretion $[\mathrm{SB} \rightarrow \mathrm{R}]_{\mathrm{N}}$ must then be constrained by parameters cnb and cnh, as shown in Eq. (3) (Table 4), in order to satisfy the nitrogen mass conservation.

\section{Modelling positive growth in Period P2}

The carbon weight of the animal $\left(\mathrm{W}_{\mathrm{C}}\right)$ is defined here as the sum of the structural biomass $\left(\mathrm{SB}_{\mathrm{C}}\right)$ and the gonads $\left(G_{C}\right)$ :

Table 4. Oikopleura dioica. Carbon and nitrogen flows for period P1 (x stands for $\mathrm{C}$ or N). Variables, parameters and flows are defined in Tables 1-3

\begin{tabular}{|c|c|c|}
\hline Flow & Carbon & Nitrogen \\
\hline$[\mathrm{SB} \rightarrow \mathrm{R}]_{X}$ & res $1 \mathrm{t} 10^{\mathrm{T}} \mathrm{SB}_{\mathrm{C}}$ & {$\left[\frac{\mathrm{res} 1}{\mathrm{cnb}}+\operatorname{chr} 1\left(\frac{1}{\mathrm{cnb}}-\frac{1}{\mathrm{cnh}}\right)\right] \mathrm{t} 10^{\mathrm{T}} \mathrm{SB}_{\mathrm{C}}$} \\
\hline$[\mathrm{SB} \rightarrow \mathrm{HR}]_{X}$ & $\operatorname{chr} 1 \mathrm{t} 10^{\mathrm{T}} \mathrm{SB}_{\mathrm{C}}$ & $\frac{\operatorname{chr} 1 \mathrm{t} 10^{\mathrm{T}} \mathrm{SB}_{\mathrm{C}}}{\mathrm{cnh}}$ \\
\hline
\end{tabular}




$$
\mathrm{W}_{\mathrm{C}}=\mathrm{SB}_{\mathrm{C}}+\mathrm{G}_{\mathrm{C}}
$$

A different definition could have been chosen (e.g. by adding to $\mathrm{W}_{\mathrm{C}}$ the weight of the house rudiment and/or that of the working house, which can be considered as elements of the body), but $\mathrm{W}_{\mathrm{C}}$ is preferred for 3 reasons: (1) it corresponds to most measurements found in the literature for appendicularian individual weights; (2) at small timescales (h), $\mathrm{W}_{\mathrm{C}}$ is much less variable than $\mathrm{W}_{\mathrm{C}}+\mathrm{HR}_{\mathrm{Ci}}$ and (3) $\mathrm{W}_{\mathrm{C}}$ is the input variable of the trunk length $\left(\mathrm{TL}_{i}\right.$ in $\left.\mu \mathrm{m}\right)$ relationship provided by King et al. (1980):

$$
\mathrm{TL}=10^{\left[\frac{\log _{10}\left(\mathrm{~W}_{\mathrm{C}}\right)+7.1348}{2.6270}\right]}
$$

The Oikopleura dioica individual enters Period P2 as soon as the carbon weight of the house rudiment $\left(\mathrm{HR}_{\mathrm{C}}\right)$ reaches a critical weight (th $\mathrm{W}_{\mathrm{C}}$ ), where parameter th (Table 2) represents a fraction of $\mathrm{W}_{\mathrm{C}}$. For O. dioica, Gorsky (1980) found that the house represents as much as $19.2 \%$ of the animal's overall carbon content, i.e. th $=0.2376$ (Table 2); Deibel (1986 1988) found 10 to $36 \%$ for $O$. vanhoeffeni, and Alldredge (1976) gave a range of 20 to $40 \%$. When $\mathrm{HR}_{\mathrm{C}} \geq$ th $\mathrm{W}_{\mathrm{C}}$, the house rudiment $\mathrm{HR}_{\mathrm{C}}$ is deployed around the animal to become a working house called $\mathrm{H}_{\mathrm{C}}$ (Table 1, Fig. 4). As specified in Table 3, the deployment of a new house $[\mathrm{HR} \rightarrow \mathrm{H}]_{x}$ is a discrete event that occurs within the time step $\mathrm{dt}$ during model implementation, as follows:

if $\mathrm{HR}_{\mathrm{C}} \geq\left(\right.$ th $\left.\mathrm{W}_{\mathrm{C}}\right)$ then

$$
\begin{gathered}
\mathrm{H}_{C}^{\mathrm{t}+\mathrm{dt}}=\mathrm{HR}_{C}^{\mathrm{t}} \\
\mathrm{HR}_{\mathrm{C}}^{\mathrm{t}+\mathrm{dt}}=0
\end{gathered}
$$

As for the house rudiment, the $\mathrm{C}: \mathrm{N}$ ratio of the working house is kept constant $\left(\mathrm{H}_{\mathrm{C}}: \mathrm{H}_{\mathrm{N}}=\mathrm{cnh}\right)$.

The $\mathrm{C}$ and $\mathrm{N}$ quantities of the food available in the medium are $\mathrm{F}_{\mathrm{C}}$ and $\mathrm{F}_{\mathrm{N}}$, respectively (Fig. 4, Table 1). The volume of seawater in the experimental bottle $\left(\mathrm{V}_{i}\right.$ in $\left.\mathrm{l}\right)$ is used to compute the concentrations of food $\left(\mathrm{F}_{\mathrm{C}}: \mathrm{V}\right.$ and $\left.\mathrm{F}_{\mathrm{N}}: \mathrm{V}\right)$. When a new house is deployed, we assume that food concentrations inside and outside the house are the same. To compute the $\mathrm{C}$ and $\mathrm{N}$ weights of the food inside the house $\left(\mathrm{HF}_{\mathrm{C}}\right.$ and $\mathrm{HF}_{\mathrm{N}}$ Eq. 8 and Fig. 4), the volume unoccupied by the animal inside the house $(\mathrm{VH})$ must be estimated. The house length HL (in $\mu m_{i}$ Eq. 5) is first deduced from TL (Eq. 2) assuming a constant size ratio $\mathrm{rl}=$ HL:TL of 3.846 (Table 2; see Flood \& Deibel 1998). Considering that the shape of the house is spherical, we then compute its volume HS (in $\mu^{3}$; Eq. 6), from which $\mathrm{VH}$ is deduced (in $l_{i}$ Eq. 7 ) using parameter fv (i.e. the fraction of HS unoccupied by the organism; Table 2) deduced from Flood et al. (1990) on Oikopleura vanhoeffeni.

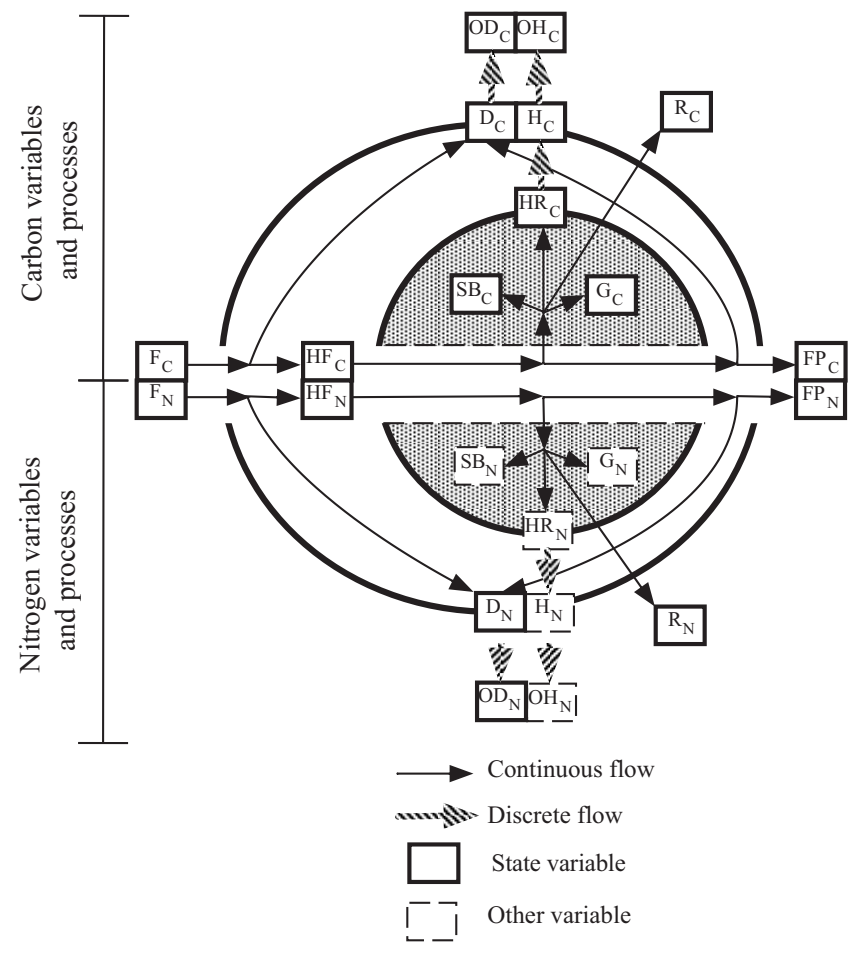

Fig. 4. Oikopleura dioica. Variables and processes used to model positive growth in Period P2 of the life cycle. Symbols and units are described in Tables 1-3

$$
\begin{gathered}
\mathrm{HL}=\mathrm{TL} \mathrm{rl} \\
\mathrm{HS}=\frac{4 \pi(\mathrm{HL} / 2)^{3}}{3} \\
\mathrm{VH}=\mathrm{HS} \mathrm{fv} 10^{-15} \\
\mathrm{HF}_{\mathrm{C}}=\frac{\mathrm{F}_{\mathrm{C}} \mathrm{VH}}{\mathrm{V}} \text { and } \mathrm{HF}_{\mathrm{N}}=\frac{\mathrm{F}_{\mathrm{N}} \mathrm{VH}}{\mathrm{V}}
\end{gathered}
$$

As soon as the first house is deployed, seawater filtration, food processing, and positive growth become possible. These processes depend largely on external conditions (food quantity and quality, temperature, etc.). All processes of the model during Period P2 are illustrated in Fig. 4. The maximum food intake rate ( $\mathrm{Im}_{\text {; }}$ $\mathrm{d}^{-1}$ ) is computed from the following allometric equation:

$$
\operatorname{Im}=\mathrm{a}\left(\mathrm{W}_{\mathrm{C}} 10^{6}\right)^{\mathrm{b}} \mathrm{t} 10^{\mathrm{T}}
$$

where parameters $\mathrm{a}$ and $\mathrm{b}$ are deduced from Acuña \& Kiefer (2000), and Moloney \& Field (1989), respectively (Table 2). The filtration rate $\mathrm{F}\left(1 \mathrm{ind} .^{-1} \mathrm{~d}^{-1}\right)$ is then given by:

$$
\begin{array}{r}
\text { if } E=0 \text { then } F=0 \\
\text { if } E \neq 0 \text { then } F=\operatorname{Im} \frac{W_{C}}{k i+\left(F_{C} / V\right)}
\end{array}
$$


where $E$ is the food retention efficiency of the pharyngeal filter (the possible range of $\mathrm{E}$ is 0 to 1 ). When $\mathrm{E}=$ 0 , the food cannot be retained by the pharyngeal filter and filtration is suspended (Eq. 10); when $0<\mathrm{E} \leq 1$ the food may be partially or totally captured by the pharyngeal filter and filtration is computed using Eq. (11). The half-saturation constant for food intake (ki = $240 \mathrm{\mu gC} \mathrm{I}^{-1}$; Table 2) is from Hansen et al. (1997). This value agrees with the experimental work of Acuña \& Kiefer (2000), who studied the functional responses of Oikopleura dioca. The food intake $\mathrm{FI}_{\mathrm{C}}\left(\mu \mathrm{gC}\right.$ ind. $\left.{ }^{-1} \mathrm{~d}^{-1}\right)$ is deduced from the filtration rate as follows:

$$
\mathrm{FI}_{\mathrm{C}}=\mathrm{F} \frac{\mathrm{F}_{\mathrm{C}}}{\mathrm{V}}
$$

Once the food is inside the house, it can remain in suspension, be ingested by the animal or it can accumulate on the inner wall of the house. The food which is effectively ingested by the animal $\left(\mathrm{I}_{\mathrm{C}} \mu \mathrm{\mu gC}\right.$ ind. $\left.{ }^{-1} \mathrm{~d}^{-1}\right)$ is calculated from the food intake $\mathrm{FI}_{\mathrm{C}}$ :

$$
\mathrm{I}_{\mathrm{C}}=\mathrm{FI}_{\mathrm{C}} \mathrm{ffi}\left[\mathrm{E}+(1-\mathrm{E}) \frac{\left(\mathrm{HF}_{\mathrm{C}} / \mathrm{VH}\right)}{\mathrm{ke}+\left(\mathrm{HF}_{\mathrm{C}} / \mathrm{VH}\right)}\right]
$$

where parameter ffi (Table 2) represents the fraction of the food intake available for ingestion. In the model, ffi $=0.95$, which means that $95 \%$ of the food intake is available for ingestion, whereas the remaining $5 \%$ accumulates on the inner wall of the house. Gorsky (1980) and Gorsky \& Palazzoli (1989) found that 25 to $37 \%$ of the material collected by appendicularians accumulate as detritus on the inner wall of the house; these higher percentages are explained by the fact that measurements were made on abandoned houses, in which the quantity of accumulated material (including feces) is largest.

From Eq. (13), 3 different cases may arise depending on the value of the retention efficiency $E$ : (1) when $E=$ 1 , all filtered food (fraction ffi) is ingested since $\mathrm{I}_{\mathrm{C}}=\mathrm{FI}_{\mathrm{C}}$ ffi $_{i}(2)$ when $\mathrm{E}=0, \mathrm{I}_{\mathrm{C}}=0$ since $\mathrm{FI}_{\mathrm{C}}=0$ (see Eqs. 10 \& 12); and (3) when $0<\mathrm{E}<1$, the food concentration inside the house $\left(\mathrm{HF}_{\mathrm{C}} / \mathrm{VH}\right)$ increases since $\mathrm{I}_{\mathrm{C}}>\mathrm{FI}_{\mathrm{C}}$ ffi. According to Morris \& Deibel (1993) and Acuña et al. (1996), the increasing concentration of food inside the house could favour the aggregation of particles, and thus result in an increase of the retention efficiency. In Eq. (13), we attempt to simulate this effect by using a Michaelis-Menten function where the food concentration affects the global retention efficiency (the term in brackets) through the difference $(1-E)$.

The respiration for maintenance $\left(\mathrm{RB}_{\mathrm{C} i}\right.$ in $\mu \mathrm{gC}$ ind. ${ }^{-1}$ $\mathrm{d}^{-1}$ ) follows the parameterisation proposed by Touratier et al. (1999) for copepods:

$$
\mathrm{RB}_{\mathrm{C}}=\operatorname{Im} \frac{\mathrm{tf}}{\mathrm{ki}+\mathrm{tf}} \mathrm{W}_{\mathrm{C}} \mathrm{ac}
$$

where $\mathrm{tf}$ is the food concentration threshold for maintenance (Table 2). Its value $\left(1 \mu \mathrm{gC} \mathrm{l}^{-1}\right)$ was deduced during model calibration. Ranges found in the literature for the carbon assimilation coefficient (ac, Table 2) are quite large: 0.17 to 0.88 for Oikopleura dioica (Gorsky 1980), and 0.42 to 0.83 for O. vanhoeffeni (Bochdansky et al. 1999). From the latter, a mean value of 0.67 is used. In the present section, growth must be positive, i.e. the carbon contained in assimilated food must exceed the metabolic requirements for maintenance $\left(\mathrm{I}_{\mathrm{C}} \mathrm{ac}>\mathrm{RB}_{\mathrm{C}}\right)$.

The parameterisation used for the $\mathrm{C}$ and $\mathrm{N}$ flows that characterise Period P2 when growth is positive (Fig. 4) is listed in Table 5. The nitrogen food intake (Eq. 9, Table 5) is computed from its carbon equivalent (Eq. 1, Table 5) by using the food $\mathrm{C}: \mathrm{N}$ ratio $\left(\mathrm{CNF}=\mathrm{F}_{\mathrm{C}}: \mathrm{F}_{\mathrm{N}}\right)$. The food that accumulates as detritus $\left(D_{C}\right.$ and $\left.D_{N}\right)$ on the inner wall of the house is computed from Eqs. (2) \& (10) (Table 5). The fraction ffp (Table 2) of the fecal pellets $\left(\mathrm{FP}_{\mathrm{C}}\right.$ and $\left.\mathrm{FP}_{\mathrm{N}}\right)$ produced by the animal is released to the medium (Eqs. 3 \& 11, Table 5), whereas the remaining part ( $1-\mathrm{ffp}$ ) accumulates as detritus on the inner wall of the house (Eqs. 8 \& 16, Table 5). To compute the nitrogen flows, the nitrogen assimilation coefficient (an, Table 2) is set to 0.72 (Bochdansky et al. 1999).

Once assimilated, the food is used for production of new biomass and for respiration/excretion. The parameterisation of these processes is based on the stoichiometric approach developed by Touratier et al. to simulate the influence of food quantity and quality on copepod growth (for details, see Touratier et al. 1999), with the following parameterisation for appendicularians.

Since ac $\neq$ an, the $\mathrm{C}: \mathrm{N}$ ratio for assimilated food (CNA) differs from that for ingested food (CNF). The relationship between the 2 ratios is given by $\mathrm{CNA}=$ $\mathrm{CNF}(\mathrm{ac}: \mathrm{an})$. The net growth efficiency K2, defined as the ratio of production over assimilation when $\mathrm{CNA}=$ $\mathrm{cnb}$, is computed as follows:

$$
\mathrm{K} 2=\mathrm{k} 2 \mathrm{~m} \frac{\mathrm{I}_{\mathrm{C}} \mathrm{ac}-\mathrm{RB}_{\mathrm{C}}}{\mathrm{kk} 2+\mathrm{I}_{\mathrm{C}} \mathrm{ac}-\mathrm{RB}_{\mathrm{C}}}
$$

Variable $\mathrm{K} 2$ reaches a maximum value $\mathrm{k} 2 \mathrm{~m}$ when ingestion $\mathrm{I}_{\mathrm{C}}$ becomes saturating, and it is null when $\left(I_{C} a c\right)=R B_{C}$. There is no estimate of $k 2 m$ for appendicularians, so that we chose a value typical of copepods, 0.44 for k2m (Table 2) (Touratier et al. 1999).

During Period P2, the production of new biomass is the sum of 3 processes: production of (1) structural biomass SB (Eqs. 4 \& 12, Table 5); (2) gonads G (Eqs. 5 \& 13, Table 5); and (3) house rudiment HR (Eqs. $7 \& 15$, Table 5). The contribution of each process to total production is computed using the fractions fsb2, fg2 and fhr, which are equal to $0.25,0.1$ and 0.65 , respectively (Table 2). These parameters are adjusted during model calibration, and 2 conditions must be satisfied concern- 
Table 5. Oikopleura dioica. Carbon and nitrogen flows for Period P2 when growth is positive $\left(\mathrm{I}_{\mathrm{C}}\right.$ ac $\left.>\mathrm{RB}_{\mathrm{C}}\right)(x$ stands for $\mathrm{C}$ or $\mathrm{N})$. Variables, parameters and flows are defined in Tables 1-3

\begin{tabular}{|c|c|c|c|c|}
\hline Flow & Carbon & & Nitrogen & \\
\hline$[\mathrm{F} \rightarrow \mathrm{HF}]_{X}$ & $\mathrm{FI}_{\mathrm{C}} \mathrm{ffi}$ & (1) & $\frac{\mathrm{FI}_{\mathrm{C}} \mathrm{ffi}}{\mathrm{CNF}}$ & (9) \\
\hline$[\mathrm{F} \rightarrow \mathrm{D}]_{X}$ & $\mathrm{FI}_{\mathrm{C}}(1-\mathrm{ffi})$ & $(2)$ & $\frac{\mathrm{FI}_{\mathrm{C}}(1-\mathrm{ffi})}{\mathrm{CNF}}$ & (10) \\
\hline$[\mathrm{HF} \rightarrow \mathrm{FP}]_{X}$ & $\mathrm{I}_{\mathrm{C}}(1-\mathrm{ac}) \mathrm{ffp}$ & (3) & $\frac{\mathrm{I}_{\mathrm{C}}(1-\mathrm{an}) \mathrm{ffp}}{\mathrm{CNF}}$ & (11) \\
\hline$[\mathrm{HF} \rightarrow \mathrm{SB}]_{X}$ & $\mathrm{I}_{\mathrm{C}} \mathrm{ac} \mathrm{K} 2 \frac{\mathrm{cnb}}{\mathrm{CNA}} \mathrm{fsb} 2$ & $(4)$ & $\frac{\mathrm{I}_{\mathrm{C}} \text { an } \mathrm{K} 2 \mathrm{fsb} 2}{\mathrm{CNF}}$ & (12) \\
\hline$[\mathrm{HF} \rightarrow \mathrm{G}]_{X}$ & $\mathrm{I}_{\mathrm{C}}$ ac $\mathrm{K} 2 \frac{\mathrm{cnb}}{\mathrm{CNA}} \mathrm{fg} 2$ & (5) & $\frac{\mathrm{I}_{\mathrm{C}} \text { an } \mathrm{K} 2 \mathrm{fg} 2}{\mathrm{CNF}}$ & (13) \\
\hline$[\mathrm{HF} \rightarrow \mathrm{R}]_{X}$ & $\mathrm{I}_{\mathrm{C}} \mathrm{ac}\left(1-\mathrm{K} 2 \frac{\mathrm{cnb}}{\mathrm{CNA}}\right)$ & (6) & $\frac{\mathrm{I}_{\mathrm{C}} \text { an }}{\mathrm{CNF}}\left[1-\mathrm{K} 2\left(\mathrm{fsb} 2+\mathrm{fg} 2+\frac{\mathrm{cnb}}{\mathrm{cnh}} \mathrm{fhr}\right)\right]$ & (14) \\
\hline$[\mathrm{HF} \rightarrow \mathrm{HR}]_{x}$ & $\mathrm{I}_{\mathrm{C}}$ ac K2$\frac{\mathrm{cnb}}{\mathrm{CNA}} \mathrm{fhr}$ & (7) & $\mathrm{I}_{\mathrm{C}}$ an $\mathrm{K} 2 \frac{\mathrm{cnb}}{\mathrm{CNF} \operatorname{cnh}} \mathrm{fhr}$ & (15) \\
\hline$[\mathrm{HF} \rightarrow \mathrm{D}]_{X}$ & $\mathrm{I}_{\mathrm{C}}(1-\mathrm{ac})(1-\mathrm{ffp})$ & (8) & $\frac{\mathrm{I}_{\mathrm{C}}(1-\mathrm{an})(1-\mathrm{ffp})}{\mathrm{CNF}}$ & (16) \\
\hline
\end{tabular}

ing their values: (1) mass conservation must be respected (fsb2 + fg $2+\mathrm{fhr}=1)$, and (2) the gain in carbon weight of the house rudiment $\left(\mathrm{HR}_{\mathrm{C}}\right)$ must be higher than that of the individual's carbon weight $\left(\mathrm{W}_{\mathrm{C}}\right.$; see Eq. 1) since the deployment of a new house depends on the comparison between $\mathrm{HR}_{\mathrm{C}}$ and $\mathrm{W}_{\mathrm{C}}$ (see above). This is done by choosing fhr $>(\mathrm{fsb} 2+\mathrm{fg} 2)$.

Respiration and excretion are simulated using Eqs. (6) \& (14) (Table 5), respectively. Mass conservation for $\mathrm{C}$ and $\mathrm{N}$ after assimilation must be satisfied: by summing Eqs. (4) to (7) for the carbon cycle, and Eqs. (12) to (15) for the nitrogen cycle (Table 5), we obtain the assimilation of carbon $\left(\mathrm{I}_{\mathrm{C}} \mathrm{ac}\right)$ and that of nitrogen $\left(\mathrm{I}_{\mathrm{C}}\right.$ an:CNF), respectively. An important characteristic of appendicularians, however, is that $\mathrm{cnh}>>$ cnb (Table 2). In order to respect these ratios, it is assumed that the organism uses 250 (i.e. cnh) times less $\mathrm{N}$ than $\mathrm{C}$ during the construction of the house rudiment (compare Eqs. 7 \& 15, Table 5). It follows that the resulting excess of $\mathrm{N}$ must be excreted to satisfy mass conservation (Eq. 14, Table 5).

The deployment of a new house consists in a sequence of discrete events that occurs as often as the house rudiment $\mathrm{C}$ content $\left(\mathrm{HR}_{\mathrm{C}}\right)$ reaches a threshold defined by the product (th $\mathrm{W}_{\mathrm{C}}$ ):

$$
\begin{gathered}
\text { if } \quad \mathrm{HR}_{\mathrm{C}} \geq\left(\text { th } \mathrm{W}_{\mathrm{C}}\right) \text { then } \\
\mathrm{OH}_{\mathrm{C}}^{\mathrm{t}+\mathrm{dt}}=\mathrm{OH}_{\mathrm{C}}^{\mathrm{t}}+\mathrm{H}_{\mathrm{C}}^{\mathrm{t}} \\
\mathrm{OD}_{\mathrm{C}}^{\mathrm{t}+\mathrm{dt}}=\mathrm{OD}_{\mathrm{C}}^{\mathrm{t}}+\mathrm{D}_{\mathrm{C} i}^{\mathrm{t}} \quad \mathrm{OD}_{\mathrm{N}}^{\mathrm{t}+\mathrm{dt}}=\mathrm{OD}_{\mathrm{N}}^{\mathrm{t}}+\mathrm{D}_{\mathrm{N}}^{\mathrm{t}} \\
\mathrm{D}_{\mathrm{C}}^{\mathrm{t}+\mathrm{dt}}=0 ; \quad \mathrm{D}_{\mathrm{N}}^{\mathrm{t} d \mathrm{dt}}=0
\end{gathered}
$$

The full sequence of events consists of Eqs. (16) to (18), then followed by Eqs. (3) \& (4) (see above). When a new house is being deployed by the animal, the old house $\left(\mathrm{H}_{\mathrm{C}}\right)$ and the detritus $\left(\mathrm{D}_{\mathrm{C}}\right.$ and $\left.\mathrm{D}_{\mathrm{N}}\right)$ are abandoned. They accumulate in the medium as old houses $\left(\mathrm{OH}_{\mathrm{C}}\right)$ and old detritus $\left(\mathrm{OD}_{\mathrm{C}}\right.$ and $\left.\mathrm{OD}_{\mathrm{N}}\right)$, as parameterized in Eqs. (16) \& (17) (see also Fig. 4). When the house rudiment $\left(\mathrm{HR}_{\mathrm{C}}\right)$ is deployed to become a working house $\left(\mathrm{H}_{\mathrm{C}}\right.$ i see Eqs. 3 \& 4$)$, there is no detritus $\left(\mathrm{D}_{\mathrm{C}}\right.$ and $\mathrm{D}_{\mathrm{N}}$ are initialized to 0 ; Eq. 18).

In the model, Oikopleura dioica enters Period P3 when trunk length TL (Eq. 2) reaches a size threshold called $\mathrm{TL}_{\mathrm{MGON}}$, computed as follows:

$$
\mathrm{TL}_{\mathrm{MGON}}=[\operatorname{atl}(\mathrm{T}-23)+\mathrm{tlm}] \mathrm{ttl}
$$

Threshold $\mathrm{TL}_{\mathrm{MGON}}$ decreases with increasing temperature. This effect is represented by a negative slope (atl; Table 2). Values for parameters atl and th (the maximum trunk length at $23^{\circ} \mathrm{C}$ ) were estimated from the experimental work of Gorsky (1980). Since the maximum TL of an individual (tlm) is observed just before the release of gametes, a fraction $t t l(0.8$, Table 2) is used to compute threshold TL $\mathrm{MGON}_{\text {(Eq. 19). }}$

\section{Modelling positive growth in Period P3}

Period P3 is characterized by development of gonads. The parameterisation used to simulate the processes involved during Period P3 (Table 6; see also Fig. 5) is similar to that used during Period P2, but with the following 3 differences: 
(1) The $C$ and $N$ used for production of structural biomass during Period P2 (Eqs. 4 \& 12; Table 5) is utilised for production of gonads during Period P3 (Eqs. 4 \& 12 in Table 6 are the sum of Eqs. 4 \& 5, and Eqs. 12 \& 13 in Table 5, respectively).

(2) Autolysis phenomena of oikoplastic and digestive cells have been observed during Period P3, indicating that some materials of the structural biomass are reinvested into the gonads. This new process is parameterised by Eqs. (8) \& (16) (Table 6). During Period P3 and positive growth, the structural biomass SB always decreases, whereas the individual weight $W_{C}$ $\left(\mathrm{SB}_{\mathrm{C}}+\mathrm{G}_{\mathrm{C}}\right)$ always increases.

(3) Release of gametes is a discrete process $\left(E_{C}\right.$, the carbon content of the gametes, is released from the gonads $\mathrm{G}_{\mathrm{C} i}$ see Table 1 and Fig. 5) that occurs as soon as the trunk length of Oikopleura dioica reaches threshold $\mathrm{TL}_{\mathrm{RG}}$, which is defined as follows:

$$
\mathrm{TL}_{\mathrm{RG}}=\operatorname{atl}(\mathrm{T}-23)+\mathrm{tlm}
$$

Table 6. Oikopleura dioica. Carbon and nitrogen flows for Period P3 when growth is positive $\left(\mathrm{I}_{\mathrm{C}}\right.$ ac $\left.>\mathrm{RB}_{\mathrm{C}}\right)(\mathrm{x}$ stands for C or N). Variables, parameters and flows are defined in Tables 1-3

\begin{tabular}{|c|c|c|c|c|}
\hline Flow & Carbon & & Nitrogen & \\
\hline$[\mathrm{F} \rightarrow \mathrm{HF}]_{X}$ & $\mathrm{FI}_{\mathrm{C}} \mathrm{ffi}$ & (1) & $\frac{\mathrm{FI}_{\mathrm{C}} \mathrm{ffi}}{\mathrm{CNF}}$ & (9) \\
\hline$[\mathrm{F} \rightarrow \mathrm{D}]_{x}$ & $\mathrm{FI}_{\mathrm{C}}(1-\mathrm{ffi})$ & $(2)$ & $\frac{\mathrm{FI}_{\mathrm{C}}(1-\mathrm{ffi})}{\mathrm{CNF}}$ & $(10)$ \\
\hline$[\mathrm{HF} \rightarrow \mathrm{FP}]_{x}$ & $I_{C}(1-a c) f f p$ & (3) & $\frac{\mathrm{I}_{\mathrm{C}}(1-\mathrm{an}) \mathrm{ffp}}{\mathrm{CNF}}$ & $(11)$ \\
\hline$[\mathrm{HF} \rightarrow \mathrm{G}]_{X}$ & $\frac{\mathrm{I}_{\mathrm{C}} \mathrm{ac} \mathrm{K} 2 \mathrm{cnb}(\mathrm{fg} 2+\mathrm{fsb} 2)}{\mathrm{CNA}}$ & $(4)$ & $\frac{\left.\mathrm{I}_{\mathrm{C}} \text { an K2(fg2 }+\mathrm{fsb} 2\right)}{\mathrm{CNF}}$ & $(12)$ \\
\hline$[\mathrm{HF} \rightarrow \mathrm{R}]_{X}$ & $\mathrm{I}_{\mathrm{C}} \mathrm{ac}\left(1-\mathrm{K} 2 \frac{\mathrm{cnb}}{\mathrm{CNA}}\right)$ & (5) & $\frac{\mathrm{I}_{\mathrm{C}} \text { an }}{\mathrm{CNF}}\left[1-\mathrm{K} 2\left(\mathrm{fsb} 2+\mathrm{fg} 2+\frac{\mathrm{cnb}}{\mathrm{cnh}} \mathrm{fhr}\right)\right]$ & $(13)$ \\
\hline$[\mathrm{HF} \rightarrow \mathrm{HR}]_{X}$ & $\frac{\mathrm{I}_{\mathrm{C}} \mathrm{ac} \mathrm{K} 2 \mathrm{cnb}}{\mathrm{CNA}} \mathrm{fhr}$ & (6) & $\mathrm{I}_{\mathrm{C}}$ an $\mathrm{K} 2 \frac{\mathrm{cnb}}{\mathrm{CNF} \mathrm{cnh}} \mathrm{fhr}$ & (14) \\
\hline$[\mathrm{HF} \rightarrow \mathrm{D}]_{X}$ & $\mathrm{I}_{\mathrm{C}}(1-\mathrm{ac})(1-\mathrm{ffp})$ & (7) & $\frac{\mathrm{I}_{\mathrm{C}}(1-\mathrm{an})(1-\mathrm{ffp})}{\mathrm{CNF}}$ & $(15)$ \\
\hline$[\mathrm{SB} \rightarrow \mathrm{G}]_{X}$ & $\operatorname{cg} 3 \mathrm{t} 10^{\mathrm{T}} \mathrm{SB}_{\mathrm{C}}$ & $(8)$ & $\frac{\operatorname{cg} 3 \mathrm{t} 10^{\mathrm{T}} \mathrm{SB}_{\mathrm{C}}}{\mathrm{cnb}}$ & $(16)$ \\
\hline
\end{tabular}

Table 7. Oikopleura dioica. Carbon and nitrogen flows for Periods $\mathrm{P} 2$ and $\mathrm{P} 3$ when growth is zero or negative $\left(\mathrm{I}_{\mathrm{C}}\right.$ ac $\left.\leq \mathrm{RB}_{\mathrm{C}}\right)$ ( $x$ stands for $\mathrm{C}$ or $\mathrm{N}$ ). Variables, parameters and flows are defined in Tables 1-3

\begin{tabular}{|c|c|c|c|c|}
\hline Flow & Carbon & & Nitrogen & \\
\hline$[\mathrm{F} \rightarrow \mathrm{HF}]_{X}$ & $\mathrm{FI}_{\mathrm{C}} \mathrm{ffi}$ & (1) & $\frac{\mathrm{FI}_{\mathrm{C}} \mathrm{ffi}}{\mathrm{CNF}}$ & (8) \\
\hline$[\mathrm{F} \rightarrow \mathrm{D}]_{X}$ & $\mathrm{FI}_{\mathrm{C}}(1-\mathrm{ffi})$ & (2) & $\frac{\mathrm{FI}_{\mathrm{C}}(1-\mathrm{ffi})}{\mathrm{CNF}}$ & (9) \\
\hline$[\mathrm{HF} \rightarrow \mathrm{FP}]_{x}$ & $I_{C}(1-a c) f f p$ & (3) & $\frac{\mathrm{I}_{\mathrm{C}}(1-\mathrm{an}) \mathrm{ffp}}{\mathrm{CNF}}$ & (10) \\
\hline$[\mathrm{HF} \rightarrow \mathrm{R}]_{X}$ & $\mathrm{I}_{\mathrm{C}} \mathrm{ac}$ & (4) & $\frac{\mathrm{I}_{\mathrm{C}} \text { an }}{\mathrm{CNF}}$ & (11) \\
\hline$[\mathrm{HF} \rightarrow \mathrm{D}]_{X}$ & $\mathrm{I}_{\mathrm{C}}(1-\mathrm{ac})(1-\mathrm{ffp})$ & (5) & $\frac{I_{C}(1-a n)(1-f f p)}{C N F}$ & (12) \\
\hline$[\mathrm{SB} \rightarrow \mathrm{R}]_{X}$ & {$\left[\mathrm{RB}_{\mathrm{C}}-\mathrm{I}_{\mathrm{C}} \mathrm{ac}\right] \frac{\mathrm{SB}_{\mathrm{C}}}{\mathrm{SB}_{\mathrm{C}}+\mathrm{G}_{\mathrm{C}}}$} & (6) & {$\left[\mathrm{RB}_{\mathrm{C}}-\mathrm{I}_{\mathrm{C}} \mathrm{ac}\right] \frac{\mathrm{SB}_{\mathrm{C}}}{\left(\mathrm{SB}_{\mathrm{C}}+\mathrm{G}_{\mathrm{C}}\right) \mathrm{cnb}}$} & (13) \\
\hline$[\mathrm{G} \rightarrow \mathrm{R}]_{X}$ & {$\left[R_{C}-I_{C}\right.$ ac $] \frac{G_{C}}{S B_{C}+G_{C}}$} & (7) & {$\left[\mathrm{RB}_{\mathrm{C}}-\mathrm{I}_{\mathrm{C}} \mathrm{ac}\right] \frac{\mathrm{G}_{\mathrm{C}}}{\left(\mathrm{SB}_{\mathrm{C}}+\mathrm{G}_{\mathrm{C}}\right) \mathrm{cnb}}$} & (14) \\
\hline
\end{tabular}




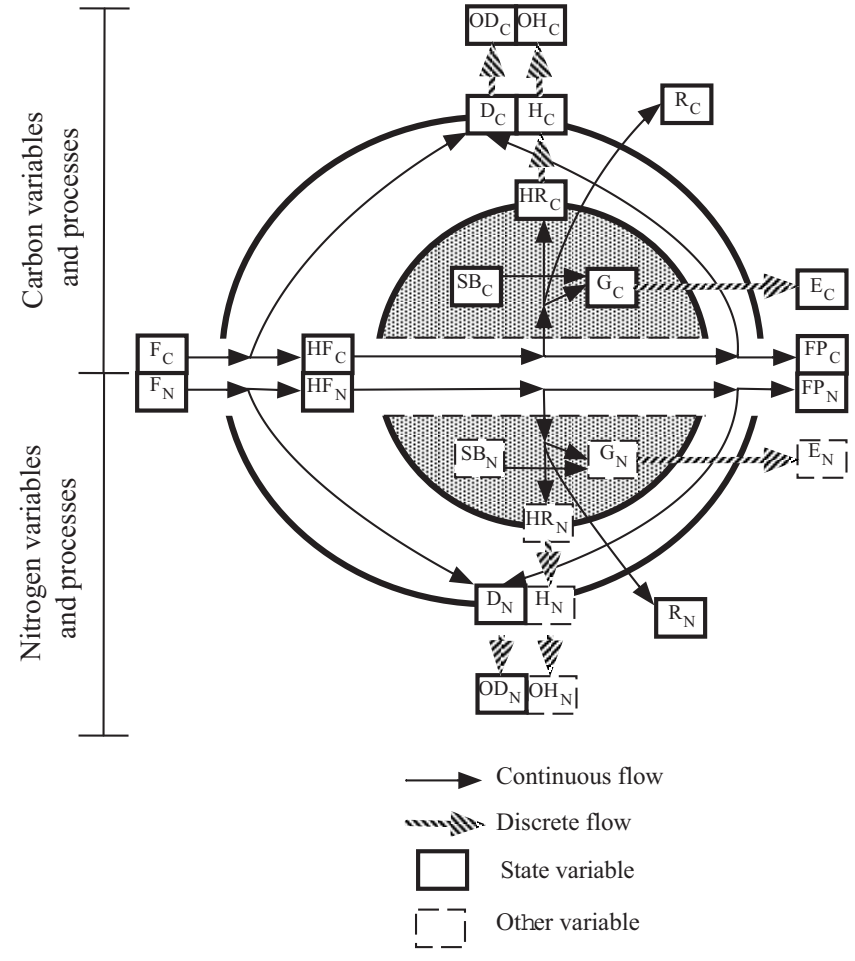

Fig. 5. Oikopleura dioica. Variables and processes used to model positive growth in Period P3 of the life cycle. Symbols and units are described in Tables 1-3

When $\mathrm{TL} \geq \mathrm{TL}_{\mathrm{RG}}$, the sequence of discrete events is given by Eqs. (16) to (18) above, followed by Eqs. (21) to (23). The old house and the associated detritus are abandoned, but there is no new house (Eq. 21) as most oikoplastic cells are empty due to the autolysis.

$$
\begin{aligned}
& \mathrm{H}_{\mathrm{C}}^{\mathrm{t}+\mathrm{dt}}=0 \\
& \mathrm{E}_{\mathrm{C}}^{\mathrm{t}+\mathrm{dt}}=\mathrm{G}_{\mathrm{C}}^{\mathrm{t}} \\
& \mathrm{G}_{\mathrm{C}}^{\mathrm{t}+\mathrm{dt}}=0
\end{aligned}
$$

\section{Modelling zero or negative growth in Periods P2 and P3}

When food concentration is very low, growth can be zero or negative. In the model, this occurs when the quantity of assimilated carbon is equal to or lower than maintenance requirements $\left(\mathrm{I}_{\mathrm{C}}\right.$ ac $\left.\leq \mathrm{RB}_{\mathrm{C}}\right)$. This is simulated using equations of Table 7 that parameterise processes appearing in Fig. 6.

Food intake (Eqs. 1 \& 8; Table 7), accumulation of food (Eqs. 2 \& 9; Table 7) and fecal pellets (Eqs. 5 \& 12; Table 7) on the inner wall of the house, and production of fecal pellets (Eqs. 3 \& 10; Table 7) are parameterised in the same way as during positive growth (see Tables 5 \& 6).
The priority of metabolism is to satisfy the costs of maintenance, and we assumed that respired or excreted products may originate from food, structural biomass, and/or gonads (Fig. 6).

When the carbon contained in the assimilated food exactly meets the metabolic requirements of the animal $\left(I_{C} a c=R B_{C}\right)$, growth is zero and respiration is computed using Eq. (4) of Table 7. All assimilated nitrogen must then be excreted in the medium to maintain the stoichiometry constant (Eq. 11, Table 7). Note also that respiration and excretion using $\mathrm{C}$ and $\mathrm{N}$ from structural biomass and gonads are all zero in this case (Eqs. 6, 7, 13, \& 14; Table 7).

For negative growth (i.e. $\mathrm{RB}_{\mathrm{C}}>\mathrm{I}_{\mathrm{C}} \mathrm{ac}>0$ ), all assimilated $\mathrm{C}$ and $\mathrm{N}$ from food is required for respiration and excretion (Eqs. 4 \& 11, Table 7). There is not enough carbon, however, to meet all metabolic requirements, so that the organism must use carbon from its structural biomass and gonads, the contribution of each compartment being proportional to their weight (Eqs. $6 \&$ 7, Table 7). The sum of Eqs. (4), (6) \& (7) (Table 7) is equal to the respiration for maintenance $\left(\mathrm{RB}_{\mathrm{C}}\right)$. To maintain the stoichiometry of SB and G constant, excretion is computed from respiration divided by ratio cnb (Eqs. 13 \& 14, Table 7).

When food assimilation is zero $\left(\mathrm{I}_{\mathrm{C}} \mathrm{ac}=0\right)$, respiration and excretion using $\mathrm{C}$ and $\mathrm{N}$ from food are zero (Eqs. 4 $\& 11$, Table 7). In this case, growth is still lower and the costs of maintenance must entirely be sustained by the $\mathrm{C}$ and $\mathrm{N}$ of SB and G (Eqs. 6, 7, 13 \& 14; Table 7).

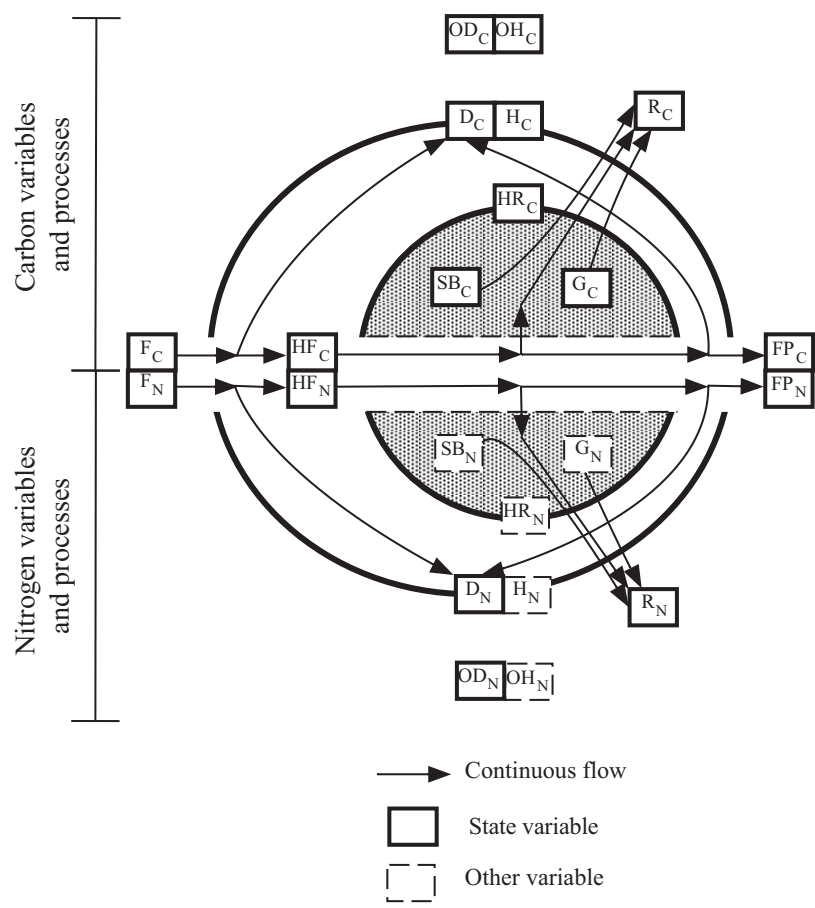

Fig. 6. Oikopleura dioica. Variables and processes used to model zero or negative growth in Periods P2 and P3 of the life cycle. Symbols and units are described in Tables 1-3 
An important consequence of negative growth is that construction of the house rudiment is stopped. This means that as long as growth is zero or negative, the animal cannot deploy a new house. Another consequence of negative growth is that release of gametes cannot occur since individual weight (and hence trunk length) is decreasing.

The system of differential equations for the model is shown in Table 8. This system is resolved using the Runge Kutta 4 th order method with a variable time step procedure.

\section{RESULTS}

\section{Behaviour of the model}

The overall behaviour of the model was explored by choosing a set of 5 experimental conditions defined as 'standard simulation': (1) volume of the experimental bottle $\mathrm{V}=0.04 \mathrm{l}_{i}(2)$ carbon weight of the food $\mathrm{F}_{\mathrm{C}}=$ $26 \mu \mathrm{gC} ;(3)$ nitrogen weight of the food $\mathrm{F}_{\mathrm{N}}=4.57 \mu \mathrm{gN}$; (4) temperature $\mathrm{T}=23^{\circ} \mathrm{C}$; and (5) food retention efficiency of the pharyngeal filter $E=1$. This set of experimental conditions (Expt 5, Table 9) was used by Gorsky (1980) to study the influence of temperature on trunk length of Oikopleura dioica. Among the 36 sets of experimental conditions that we used later to test the model (Table 9), Expt 5 was chosen as the standard simulation, because growth of $O$. dioica is maximized (one of the shortest generation times: $3.23 \mathrm{~d}$ from

Table 8. Differential equations of the growth model of Oikopleura dioica

$$
\begin{aligned}
\mathrm{d}\left(\mathrm{D}_{\mathrm{C}}\right) / \mathrm{dt}= & {[\mathrm{F} \rightarrow \mathrm{D}]_{\mathrm{C}}+[\mathrm{HF} \rightarrow \mathrm{D}]_{\mathrm{C}}-[\mathrm{D} \rightarrow \mathrm{OD}]_{\mathrm{C}} } \\
\mathrm{d}\left(\mathrm{D}_{\mathrm{N}}\right) / \mathrm{dt}= & {[\mathrm{F} \rightarrow \mathrm{D}]_{\mathrm{N}}+[\mathrm{HF} \rightarrow \mathrm{D}]_{\mathrm{N}}-[\mathrm{D} \rightarrow \mathrm{OD}]_{\mathrm{N}} } \\
\mathrm{d}\left(\mathrm{E}_{\mathrm{C}}\right) / \mathrm{dt}= & {[\mathrm{G} \rightarrow \mathrm{E}]_{\mathrm{C}} } \\
\mathrm{d}\left(\mathrm{F}_{\mathrm{C}}\right) / \mathrm{dt}= & -[\mathrm{F} \rightarrow \mathrm{HF}]_{\mathrm{C}}-[\mathrm{F} \rightarrow \mathrm{D}]_{\mathrm{C}} \\
\mathrm{d}\left(\mathrm{F}_{\mathrm{N}}\right) / \mathrm{dt}= & -[\mathrm{F} \rightarrow \mathrm{HF}]_{\mathrm{N}}-[\mathrm{F} \rightarrow \mathrm{D}]_{\mathrm{N}} \\
\mathrm{d}\left(\mathrm{FP}_{\mathrm{C}}\right) / \mathrm{dt}= & {[\mathrm{HF} \rightarrow \mathrm{FP}]_{\mathrm{C}} } \\
\mathrm{d}\left(\mathrm{FP}_{\mathrm{N}}\right) / \mathrm{dt}= & {[\mathrm{HF} \rightarrow \mathrm{FP}]_{\mathrm{N}} } \\
\mathrm{d}\left(\mathrm{G}_{\mathrm{C}}\right) / \mathrm{dt}= & =[\mathrm{HF} \rightarrow \mathrm{G}]_{\mathrm{C}}+[\mathrm{SB} \rightarrow \mathrm{G}]_{\mathrm{C}}-[\mathrm{G} \rightarrow \mathrm{R}]_{\mathrm{C}}-[\mathrm{G} \rightarrow \mathrm{E}]_{\mathrm{C}} \\
\mathrm{d}\left(\mathrm{H}_{\mathrm{C}}\right) / \mathrm{dt}= & {[\mathrm{HR} \rightarrow \mathrm{H}]_{\mathrm{C}}-[\mathrm{H} \rightarrow \mathrm{OH}]_{\mathrm{C}} } \\
\mathrm{d}\left(\mathrm{HF}_{\mathrm{C}}\right) / \mathrm{dt}= & {[\mathrm{F} \rightarrow \mathrm{HF}]_{\mathrm{C}}-[\mathrm{HF} \rightarrow \mathrm{FP}]_{\mathrm{C}}-[\mathrm{HF} \rightarrow \mathrm{SB}]_{\mathrm{C}}-[\mathrm{HF} \rightarrow \mathrm{G}]_{\mathrm{C}} } \\
& -[\mathrm{HF} \rightarrow \mathrm{R}]_{\mathrm{C}}-[\mathrm{HF} \rightarrow \mathrm{HR}]_{\mathrm{C}}-[\mathrm{HF} \rightarrow \mathrm{D}]_{\mathrm{C}} \\
\mathrm{d}\left(\mathrm{HF}_{\mathrm{N}}\right) / \mathrm{dt}= & {[\mathrm{F} \rightarrow \mathrm{HF}]_{\mathrm{N}}-[\mathrm{HF} \rightarrow \mathrm{FP}]_{\mathrm{N}}-[\mathrm{HF} \rightarrow \mathrm{SB}]_{\mathrm{N}}-[\mathrm{HF} \rightarrow \mathrm{G}]_{\mathrm{N}} } \\
& -[\mathrm{HF} \rightarrow \mathrm{R}]_{\mathrm{N}}-[\mathrm{HF} \rightarrow \mathrm{HR}]_{\mathrm{N}}-[\mathrm{HF} \rightarrow \mathrm{D}]_{\mathrm{N}} \\
\mathrm{d}\left(\mathrm{HR}_{\mathrm{C}}\right) / \mathrm{dt}= & {[\mathrm{HF} \rightarrow \mathrm{HR}]_{\mathrm{C}}+[\mathrm{SB} \rightarrow \mathrm{HR}]_{\mathrm{C}}-[\mathrm{HR} \rightarrow \mathrm{H}]_{\mathrm{C}} } \\
\mathrm{d}\left(\mathrm{OD}_{\mathrm{C}}\right) / \mathrm{dt}= & {[\mathrm{D} \rightarrow \mathrm{OD}]_{\mathrm{C}} } \\
\mathrm{d}\left(\mathrm{OD}_{\mathrm{N}}\right) / \mathrm{dt}= & {[\mathrm{D} \rightarrow \mathrm{OD}]_{\mathrm{N}} } \\
\mathrm{d}\left(\mathrm{OH}_{\mathrm{C}}\right) / \mathrm{dt}= & {[\mathrm{H} \rightarrow \mathrm{OH}]_{\mathrm{C}} } \\
\mathrm{d}\left(\mathrm{R}_{\mathrm{C}}\right) / \mathrm{dt}= & {[\mathrm{HF} \rightarrow \mathrm{R}]_{\mathrm{C}}+[\mathrm{SB} \rightarrow \mathrm{R}]_{\mathrm{C}}+[\mathrm{G} \rightarrow \mathrm{R}]_{\mathrm{C}} } \\
\mathrm{d}\left(\mathrm{R}_{\mathrm{N}}\right) / \mathrm{dt}= & {[\mathrm{HF} \rightarrow \mathrm{R}]_{\mathrm{N}}+[\mathrm{SB} \rightarrow \mathrm{R}]_{\mathrm{N}}+[\mathrm{G} \rightarrow \mathrm{R}]_{\mathrm{N}} } \\
\mathrm{d}\left(\mathrm{SB}_{\mathrm{C}}\right) / \mathrm{dt}= & =[\mathrm{HF} \rightarrow \mathrm{SB}]_{\mathrm{C}}-[\mathrm{SB} \rightarrow \mathrm{G}]_{\mathrm{C}}-[\mathrm{SB} \rightarrow \mathrm{R}]_{\mathrm{C}}-[\mathrm{SB} \rightarrow \mathrm{HR}]_{\mathrm{C}}
\end{aligned}
$$

hatching to release of gametes). Expt 5 is characterised by $\mathrm{C}$ and $\mathrm{N}$ food concentrations of $650 \mu \mathrm{gC} \mathrm{l}^{-1}$ and $114.25 \mu \mathrm{gN} \mathrm{l}^{-1}$, respectively, and $\mathrm{CNF}=5.68 \mu \mathrm{gC}$ $\mu \mathrm{gN}^{-1}$, which is the Redfield ratio. The model is designed to simulate the growth of only 1 individual contained in an experimental bottle. In permanent routine cultures of appendicularian species (e.g. Fenaux \& Gorsky 1985, Gorsky et al. 1987), animals are usually moved to a new bottle (at least once a day) where initial food levels are restored. To keep track of products released or abandoned by the animal, our simulated individual was maintained in the same bottle, but the food level was reinitialised every day at the first time step after midnight. The simulation assumes that products that accumulate in the bottle (old houses and detritus, $\mathrm{CO}_{2}, \mathrm{NH}_{4}{ }^{+}$) do not affect growth conditions.

In standard simulation the duration of the life cycle from hatching to death is $3.23 \mathrm{~d}$. The individual spends 4.1, 77.1, and $18.8 \%$ of its life in Periods P1, P2 and P3, respectively (Fig. 7). Similar percentages of 6.5, 80.4, and $13.1 \%$ were estimated by Fenaux \& Gorsky (1983) for Oikopleura longicauda, despite different experimental conditions.

Each day, larger quantities of food are filtered by the growing Oikopleura dioica $\left(\mathrm{F}_{\mathrm{C}}\right.$, Fig. 7a), but food quantity is never limiting. The carbon weight of fecal pellets $\left(\mathrm{FP}_{\mathrm{C}}\right)$ accumulates continuously in the bottle, reaching ca. $8 \mu \mathrm{gC}$ at the end of P3 (Fig. 7a). Both the structural biomass $\left(\mathrm{SB}_{\mathrm{C}}\right)$ and the gonads $\left(\mathrm{G}_{\mathrm{C}}\right)$ increase during P2 (Fig. 7b). During P3, the construction of gonads is accelerated, whereas the structural biomass slowly decreases due to autolysis. At the end of P3, all gametes are released in the medium from the gonads and $\mathrm{G}_{\mathrm{C}}=0$.

The deployment of the house rudiments is illustrated in Fig. $7 \mathrm{c}$. The carbon contained in the house rudiment $\left(\mathrm{HR}_{\mathrm{C}}\right)$ is regularly transferred to a new working house $\left(\mathrm{H}_{\mathrm{C}}\right)$. Each time, $\mathrm{HR}_{\mathrm{C}}$ becomes zero and $\mathrm{H}_{\mathrm{C}}$ increases by a step. Both $\mathrm{HR}_{\mathrm{C}}$ and $\mathrm{H}_{\mathrm{C}}$ increase proportionally to the individual weight, whereas the frequency of house renewal decreases. Detritus $\left(D_{C}\right)$ accumulates on the inner wall of the working house $\left(\mathrm{H}_{\mathrm{C}}\right)$ as soon as the new house is deployed (Fig. $7 \mathrm{~d}$ ). The abandoned houses and their associated detritus sink to the bottom of the experimental bottle to accumulate as old houses $\left(\mathrm{OH}_{\mathrm{C}}\right)$ and old detritus $\left(\mathrm{OD}_{\mathrm{C}}\right.$; Fig. 7e).

The respiration $R_{C}$ of the individual generates $\mathrm{CO}_{2}$ that accumulates in the bottle (Fig. 7f). The individual weight $\mathrm{W}_{\mathrm{C}}$ (Fig. $7 \mathrm{~g}$ ) is defined as the sum of $\mathrm{SB}_{\mathrm{C}}$ and $\mathrm{G}_{\mathrm{C}}$ (Fig. 7b), but in practice the individual weight measured in laboratory may include the weight of the house rudiment and sometimes that of the house. $\mathrm{TW}_{\mathrm{C}}$ $\left(=\mathrm{W}_{\mathrm{C}}+\mathrm{HR}_{\mathrm{C}}+\mathrm{H}_{\mathrm{C}}\right.$ ) represents the upper boundary for the individual weight (Fig. 7g). Consequently, the 
Table 9. Experiments used to validate the individual growth model of Oikopleura dioica. The 5 experimental conditions required to run the model are: $\mathrm{V}$, volume of seawater containing 1 individual $(1) ; \mathrm{F}_{\mathrm{C}}$ carbon weight of the food $(\mu \mathrm{gC}) ; \mathrm{F}_{\mathrm{N}}$, nitrogen weight of the food $(\mu \mathrm{gN}) ; \mathrm{T}$, temperature $\left({ }^{\circ} \mathrm{C}\right) ; \mathrm{E}$, capture efficiency of the pharyngeal filter (without dimension). Other data shown: $\mathrm{F}_{\mathrm{C}} / \mathrm{V}$, food concentration $\left(\mu \mathrm{gC}{ }^{-1}\right) ; \mathrm{F}_{\mathrm{C}} / \mathrm{F}_{\mathrm{N}}, \mathrm{C}: \mathrm{N}$ ratio of the food $\left(\mu \mathrm{gC} \mu \mathrm{gN}^{-1}\right)$

\begin{tabular}{|c|c|c|c|c|c|c|c|c|c|}
\hline Study & Expt & $\mathrm{V}$ & $\mathrm{F}_{\mathrm{C}}$ & $\mathrm{F}_{\mathrm{N}}$ & $\mathrm{T}$ & E & $\frac{\mathrm{F}_{\mathrm{C}}}{\mathrm{V}}$ & $\frac{F_{C}}{F_{N}}$ & Source \\
\hline $\begin{array}{l}\text { Influence of food } \\
\text { level on TL }\end{array}$ & $\begin{array}{l}1 \\
2 \\
3 \\
4\end{array}$ & $\begin{array}{c}0.1^{\mathrm{a}} \\
0.05^{\mathrm{a}} \\
0.02^{\mathrm{a}} \\
0.005^{\mathrm{a}}\end{array}$ & $\begin{array}{l}26^{\mathrm{b}} \\
13^{\mathrm{b}} \\
5.2^{\mathrm{b}} \\
1.3^{\mathrm{b}}\end{array}$ & $\begin{array}{l}4.57 \\
2.28 \\
0.91 \\
0.22\end{array}$ & $\begin{array}{l}23^{\mathrm{a}} \\
23^{\mathrm{a}} \\
23^{\mathrm{a}} \\
23^{\mathrm{a}}\end{array}$ & $\begin{array}{l}1 \\
1 \\
1 \\
1\end{array}$ & $\begin{array}{l}260 \\
260 \\
260 \\
260\end{array}$ & $\begin{array}{l}5.68 \\
5.68 \\
5.68 \\
5.68\end{array}$ & $\begin{array}{l}\text { Gorsky (1980) } \\
\text { Gorsky (1980) } \\
\text { Gorsky (1980) } \\
\text { Gorsky (1980) }\end{array}$ \\
\hline $\begin{array}{l}\text { Influence of } \mathrm{T} \text { on } \mathrm{TL} \\
\text { and generation time }\end{array}$ & $\begin{array}{c}5 \\
6 \\
7 \\
8 \\
9 \\
10 \\
11 \\
12 \\
13 \\
14\end{array}$ & $\begin{array}{c}0.04^{\mathrm{aa}} \\
0.04^{\mathrm{aa}} \\
0.04^{\mathrm{a}} \\
4 \\
4^{\mathrm{b}} \\
4^{\mathrm{b}} \\
4^{\mathrm{b}} \\
4^{\mathrm{b}} \\
4 \\
4\end{array}$ & $\begin{array}{c}26^{\mathrm{b}} \\
26^{\mathrm{b}} \\
26^{\mathrm{b}} \\
2563.2 \\
2144^{\mathrm{b}} \\
3424^{\mathrm{b}} \\
2563.2 \\
2563.2 \\
2563.2 \\
2563.2\end{array}$ & $\begin{array}{c}4.57 \\
4.57 \\
4.57 \\
451.42 \\
377.59 \\
603.06 \\
451.42 \\
451.42 \\
451.42 \\
451.42\end{array}$ & $\begin{array}{c}23^{\mathrm{a}} \\
20^{\mathrm{a}} \\
13^{\mathrm{a}} \\
5 \\
7.5^{\mathrm{a}} \\
12^{\mathrm{a}} \\
16^{\mathrm{a}} \\
18^{\mathrm{a}} \\
20 \\
25\end{array}$ & $\begin{array}{l}1 \\
1 \\
1 \\
1 \\
1 \\
1 \\
1 \\
1 \\
1 \\
1\end{array}$ & $\begin{array}{c}650 \\
650 \\
650 \\
640.8 \\
536 \\
856 \\
640.8 \\
640.8 \\
640.8 \\
640.8\end{array}$ & $\begin{array}{l}5.68 \\
5.68 \\
5.68 \\
5.68 \\
5.68 \\
5.68 \\
5.68 \\
5.68 \\
5.68 \\
5.68\end{array}$ & $\begin{array}{l}\text { Gorsky (1980) } \\
\text { Gorsky (1980) } \\
\text { Gorsky (1980) } \\
\text { Simulation }{ }^{c} \\
\text { Paffenhöfer (1976) } \\
\text { Paffenhöfer (1976) } \\
\text { Paffenhöfer (1976) } \\
\text { Paffenhöfer (1976) } \\
\text { Simulation }^{c} \\
\text { Simulation }^{c}\end{array}$ \\
\hline $\begin{array}{l}\text { Influence of food quality } \\
\text { (C:N ratio) on TL } \\
\text { Influence of TL on } \\
\text { the filtration rate }\end{array}$ & $\begin{array}{l}15 \\
16 \\
17 \\
18 \\
19 \\
20\end{array}$ & $\begin{array}{c}0.1^{\mathrm{a}} \\
0.1^{\mathrm{a}} \\
0.125^{\mathrm{a}} \\
1 \\
0.05^{\mathrm{a}} \\
1^{\mathrm{b}}\end{array}$ & $\begin{array}{c}44.98^{\mathrm{b}} \\
44.98^{\mathrm{b}} \\
12.525^{\mathrm{b}} \\
52.5^{\mathrm{b}} \\
26^{\mathrm{b}} \\
53.92^{\mathrm{b}}\end{array}$ & $\begin{array}{c}7.06 \\
4.49 \\
2.20 \\
13.12 \\
4.57 \\
9.49\end{array}$ & $\begin{array}{c}17^{\mathrm{a}} \\
17^{\mathrm{a}} \\
23.5^{\mathrm{a}} \\
13.5^{\mathrm{a}} \\
17^{\mathrm{a}} \\
13^{\mathrm{a}}\end{array}$ & $\begin{array}{c}1 \\
1 \\
1 \\
0.2 \\
1 \\
1\end{array}$ & $\begin{array}{c}449.8 \\
449.8 \\
100.2 \\
52.5 \\
520 \\
53.92\end{array}$ & $\begin{array}{c}6.37 \\
10 \\
5.68 \\
4 \\
5.68 \\
5.68\end{array}$ & $\begin{array}{l}\text { Nin (1997) } \\
\text { Nin (1997) } \\
\text { Alldredge (1981) } \\
\text { King et al. (1980) } \\
\text { Gorsky (1980) } \\
\text { Paffenhöfer (1976) }\end{array}$ \\
\hline $\begin{array}{l}\text { Influence of } \mathrm{T} \text { and } \mathrm{TL} \\
\text { on respiration }\end{array}$ & $\begin{array}{l}21 \\
22 \\
23\end{array}$ & $\begin{array}{l}0.25^{\mathrm{a}} \\
0.25^{\mathrm{a}} \\
0.25^{\mathrm{a}}\end{array}$ & $\begin{array}{l}17.5^{\mathrm{b}} \\
17.5^{\mathrm{b}} \\
17.5^{\mathrm{b}}\end{array}$ & $\begin{array}{l}3.08 \\
3.08 \\
3.08\end{array}$ & $\begin{array}{l}15^{\mathrm{a}} \\
20^{\mathrm{a}} \\
24^{\mathrm{a}}\end{array}$ & $\begin{array}{l}1 \\
1 \\
1\end{array}$ & $\begin{array}{l}70 \\
70 \\
70\end{array}$ & $\begin{array}{l}5.68 \\
5.68 \\
5.68\end{array}$ & $\begin{array}{l}\text { Gorsky et al. (1987) } \\
\text { Gorsky et al. (1987) } \\
\text { Gorsky et al. (1987) }\end{array}$ \\
\hline $\begin{array}{l}\text { Influence of } \mathrm{T} \text { and } \mathrm{TL} \\
\text { on excretion }\end{array}$ & $\begin{array}{l}24 \\
25 \\
26\end{array}$ & $\begin{array}{l}0.1^{\mathrm{a}} \\
0.1^{\mathrm{a}} \\
0.1^{\mathrm{a}}\end{array}$ & $\begin{array}{l}7^{\mathrm{b}} \\
7^{\mathrm{b}} \\
7^{\mathrm{b}}\end{array}$ & $\begin{array}{l}1.23 \\
1.23 \\
1.23\end{array}$ & $\begin{array}{l}15^{\mathrm{a}} \\
20^{\mathrm{a}} \\
24^{\mathrm{a}}\end{array}$ & $\begin{array}{l}1 \\
1 \\
1\end{array}$ & $\begin{array}{l}70 \\
70 \\
70\end{array}$ & $\begin{array}{l}5.68 \\
5.68 \\
5.68\end{array}$ & $\begin{array}{l}\text { Gorsky et al. (1987) } \\
\text { Gorsky et al. (1987) } \\
\text { Gorsky et al. (1987) }\end{array}$ \\
\hline $\begin{array}{l}\text { Influence of } \mathrm{T} \text { and } \\
\mathrm{TL} \text { on the house } \\
\text { production rate }\end{array}$ & $\begin{array}{l}27 \\
28 \\
29 \\
30 \\
31 \\
32 \\
33 \\
34 \\
35 \\
36\end{array}$ & $\begin{array}{c}0.035 \\
0.035 \\
0.035^{\mathrm{a}} \\
0.035^{\mathrm{a}} \\
0.035^{\mathrm{a}} \\
0.035^{\mathrm{a}} \\
0.035^{\mathrm{a}} \\
0.035 \\
1 \\
1\end{array}$ & $\begin{array}{c}26 \\
26 \\
26 \\
26 \\
26 \\
26 \\
26 \\
26 \\
136.1^{\mathrm{a}} \\
136.1^{\mathrm{a}}\end{array}$ & $\begin{array}{l}4.57 \\
4.57 \\
4.57 \\
4.57 \\
4.57 \\
4.57 \\
4.57 \\
4.57 \\
21.36 \\
21.36\end{array}$ & $\begin{array}{c}5 \\
10 \\
14^{\mathrm{a}} \\
16^{\mathrm{a}} \\
18^{\mathrm{a}} \\
20^{\mathrm{a}} \\
22^{\mathrm{a}} \\
25 \\
13^{\mathrm{a}} \\
20^{\mathrm{a}}\end{array}$ & $\begin{array}{l}1 \\
1 \\
1 \\
1 \\
1 \\
1 \\
1 \\
1 \\
1 \\
1\end{array}$ & $\begin{array}{l}742.8 \\
742.8 \\
742.8 \\
742.8 \\
742.8 \\
742.8 \\
742.8 \\
742.8 \\
136.1 \\
136.1\end{array}$ & $\begin{array}{l}5.68 \\
5.68 \\
5.68 \\
5.68 \\
5.68 \\
5.68 \\
5.68 \\
5.68 \\
6.37 \\
6.37 \\
\end{array}$ & $\begin{array}{l}\text { Simulation }^{c} \\
\text { Simulation }^{c} \\
\text { Fenaux (1985) } \\
\text { Fenaux (1985) } \\
\text { Fenaux (1985) } \\
\text { Fenaux (1985) } \\
\text { Fenaux (1985) } \\
\text { Simulation }{ }^{c} \\
\text { Gorsky (1980) } \\
\text { Gorsky (1980) }\end{array}$ \\
\hline
\end{tabular}

measured individual weights should be somewhere between $\mathrm{W}_{\mathrm{C}}$ and $\mathrm{TW}_{\mathrm{C}}$, depending on the presence/ absence of the house rudiment and house around the animal.

Food C:N ratio (CNF) is kept constant at $5.68 \mu \mathrm{gC}$ $\mu \mathrm{gN}^{-1}$ during the standard simulation; fecal pellets have a higher $\mathrm{C}: \mathrm{N}$ ratio of $6.69 \mu \mathrm{gC} \mu \mathrm{gN}^{-1}$ (Fig. $7 \mathrm{~h}$ ), since an $>$ ac (Table 2). C:N ratios for detritus $\left(D_{C}: D_{N}\right)$ and old detritus $\left(\mathrm{OD}_{\mathrm{C}}: \mathrm{OD}_{\mathrm{N}}\right)$ are equal (ca. $5.9 \mu \mathrm{gC}$ $\mu \mathrm{gN}^{-1}$; Fig. 7i). Since detritus originates from food and fecal pellets, its $\mathrm{C}: \mathrm{N}$ ratio mirrors their relative contributions. During P1, the C:N ratio for respired over excreted products is very low with $\mathrm{R}_{\mathrm{C}}: \mathrm{R}_{\mathrm{N}}=0.17 \mu \mathrm{gC}$ $\mu \mathrm{gN}^{-1}$ (Fig. 7j). The construction of the house rudiment during P1 is a predominant process (Fig. 3 and Table 4) responsible for the extremely low value of $R_{C}: R_{N}$. Relative to respiration, ammonium excretion is increased (excess $\mathrm{N}$ is eliminated) to maintain a constant $\mathrm{cnh}$ ratio in the house rudiment. Thereafter, during Periods $\mathrm{P} 2$ and $\mathrm{P} 3, \mathrm{R}_{\mathrm{C}}: \mathrm{R}_{\mathrm{N}}$ increases to about $3.5 \mu \mathrm{gC} \mu \mathrm{gN}^{-1}$ due to the beginning of feeding large quantities of high quality food (i.e. CNF ratio). Nutrition affects respiration, excretion, and their ratios. The elemental composition of the structural biomass, of the gonads (i.e. $\mathrm{cnb}$; 

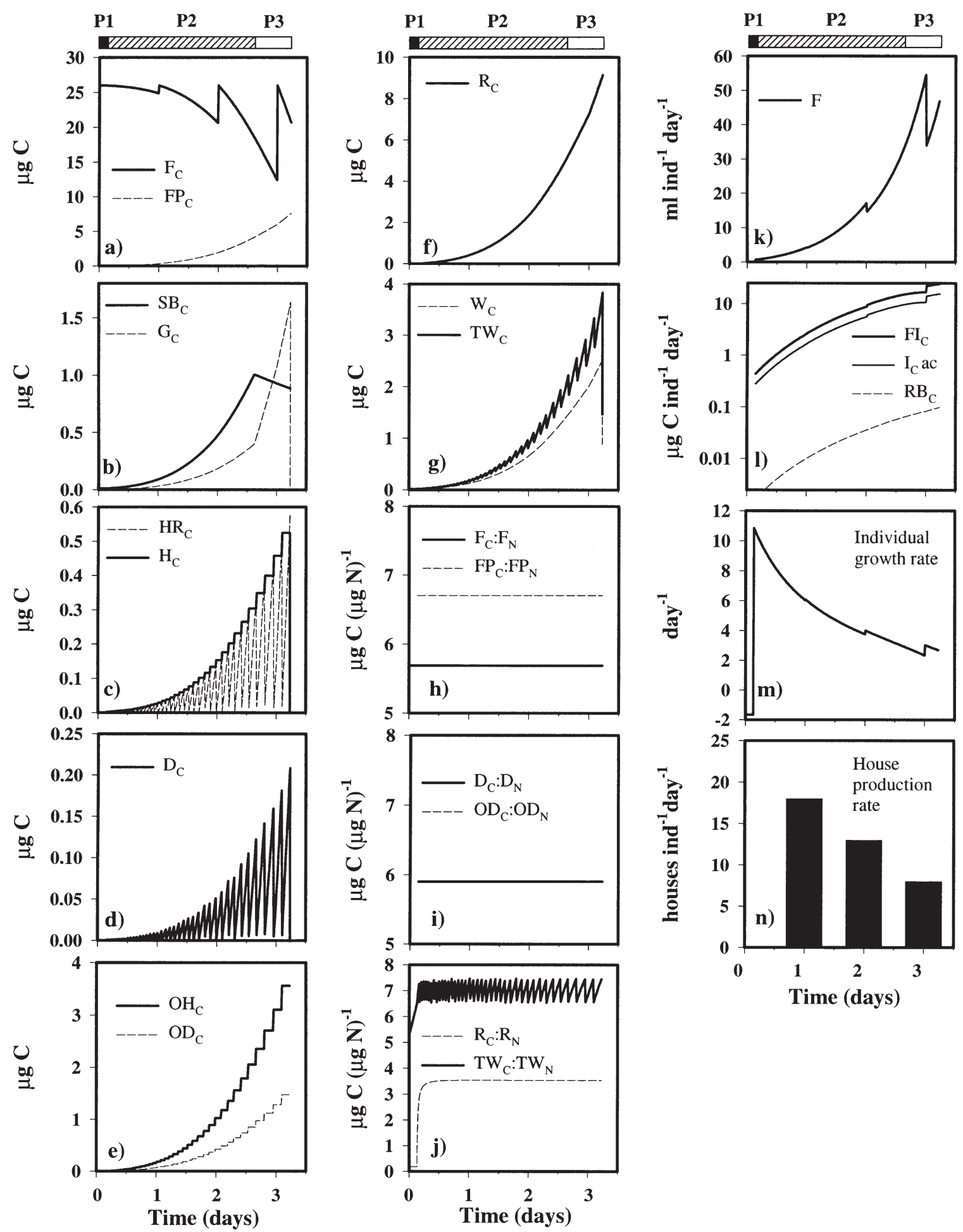

Time (days)

Fig. 7. Oikopleura dioica. Results of the model for the standard simulation: (a) carbon weight of food $\left(\mathrm{F}_{\mathrm{C}}\right)$ and fecal pellets $\left(\mathrm{FP}_{\mathrm{C}}\right)$ in the medium; (b) carbon weight of the structural biomass $\left(\mathrm{SB}_{\mathrm{C}}\right)$ and gonads $\left(\mathrm{G}_{\mathrm{C}}\right)_{i}(\mathrm{c})$ carbon weight of the house rudiment $\left(\mathrm{HR}_{\mathrm{C}}\right)$ and of the working house $\left(\mathrm{H}_{\mathrm{C}}\right)_{i}(\mathrm{~d})$ carbon weight of detritus accumulated on the inner wall of the working house $\left(\mathrm{D}_{\mathrm{C}}\right)_{i}(\mathrm{e})$ carbon weight of abandoned houses $\left(\mathrm{OH}_{\mathrm{C}}\right)$ and of detritus accumulated on their inner wall $\left(\mathrm{OD}_{\mathrm{C}}\right)_{i}$ (f) carbon weight of respired products $\left(\mathrm{R}_{\mathrm{C}}\right)_{i}(\mathrm{~g})$ individual carbon weights $\left(\mathrm{W}_{\mathrm{C}} \text { and } \mathrm{TW}_{\mathrm{C}}\right)_{i}(\mathrm{~h}) \mathrm{C}: \mathrm{N}$ ratio of food $\left(\mathrm{F}_{\mathrm{C}}: \mathrm{F}_{\mathrm{N}}\right)$ and fecal pellets $\left(\mathrm{FP}_{\mathrm{C}}: \mathrm{FP}_{\mathrm{N}}\right)$ in the medium; $(\mathrm{i}) \mathrm{C}: \mathrm{N}$ ratio of detritus accumulated on the inner wall of the working house $\left(D_{C}: D_{N}\right)$ and of abandoned houses $\left(O_{C}: O D_{N}\right) ;(j) C: N$ ratio of respired to excreted products $\left(\mathrm{R}_{\mathrm{C}}: \mathrm{R}_{\mathrm{N}}\right)$, and $\mathrm{C}: \mathrm{N}$ ratio of the individual $\left(\mathrm{TW}_{\mathrm{C}}: \mathrm{TW}_{\mathrm{N}}\right) ;(\mathrm{k})$ filtration rate $(\mathrm{F}) ;(\mathrm{l})$ carbon food intake $\left(\mathrm{FI}_{\mathrm{C}}\right)$, carbon assimilation $\left(\mathrm{I}_{\mathrm{C}} \mathrm{ac}\right)$ and respiration for maintenance $\left(\mathrm{RB}_{\mathrm{C}}\right)$; $(\mathrm{m})$ individual growth rate; $(\mathrm{n})$ house production rate. 
Table 2), and hence that of the individual (i.e. ratio $\mathrm{W}_{\mathrm{C}}: \mathrm{W}_{\mathrm{N}}$ ) remain constant. Ratio $\mathrm{TW}_{\mathrm{C}}: \mathrm{TW}_{\mathrm{N}}$, defined as $\left(\mathrm{W}_{\mathrm{C}}+\mathrm{HR}_{\mathrm{C}}+\mathrm{H}_{\mathrm{C}}\right):\left(\mathrm{W}_{\mathrm{N}}+\mathrm{HR}_{\mathrm{N}}+\mathrm{H}_{\mathrm{N}}\right)$, ranges from cnb to ca. 7.3 (Fig. 7j). This variability is induced mainly by the weight of the house rudiment $\left(\mathrm{HR}_{\mathrm{C} i}\right.$ Fig. $\left.{ }^{7 \mathrm{C}}\right)$ that changes the relative contribution of $\mathrm{cnh}$ within $\mathrm{TW}_{\mathrm{C}}: \mathrm{TW}_{\mathrm{N}}$.

The filtration rate F (Fig. 7k) computed from Eqs. (10) \& (11) increases with $\mathrm{W}_{\mathrm{C}}$ (Fig. $7 \mathrm{~g}$ ). The jumps of $\mathrm{F}$ at the beginning of Days 2 and 3 are due to the daily restoration of the food level (Fig. $7 \mathrm{a}$ ). The sudden variation in the food level also affects food intake $\left(\mathrm{FI}_{\mathrm{C}}\right)$ and assimilation of carbon $\left(\mathrm{I}_{\mathrm{C}} \mathrm{ac}\right)$, as shown in Fig. 71. Growth is negative during Period P1, but it is positive during Periods P2 and P3 (Fig. 7m) since assimilated carbon always exceeds largely maintenance needs $\left(\mathrm{I}_{\mathrm{C}}\right.$ ac $>\mathrm{RB}_{\mathrm{C}}$ Fig. 71). Just after Period P1, the growth rate reaches a maximum of ca. $11 \mathrm{~d}^{-1}$. It then decreases slowly to a minimum of ca. $2 \mathrm{~d}^{-1}$ with the increasing individual weight.

During the first day of the life period, 18 houses are produced by the animal (Fig. $7 \mathrm{n}$ ). The rate is then lowered to 13 and 8 houses during Days 2 and 3, respectively.

From the standard simulation, a carbon budget can be drawn for the individual. From the $25.38 \mu \mathrm{gC}$ of food filtered by the organism during the $3.23 \mathrm{~d}$ of its lifetime, $5.8 \%$ ends as detritus $\left(\mathrm{OD}_{\mathrm{C}}\right), 14 \%$ is in the form of old houses $\left(\mathrm{OH}_{\mathrm{C}}\right), 36 \%$ is respired $\left(\mathrm{R}_{\mathrm{C}}\right), 30 \%$ is ejected as faecal pellets, and $6.42 \%$ is invested into the eggs. The remaining $7.8 \%$ represents the cadaver of the individual. A considerable amount of carbon is lost through respiration, but $58 \%$ of the carbon ingested by an individual may sink in the water column as large particles.

\section{Comparison between observations and model output}

Several experimental data sets for Oikopleura dioica were used to test the response of the individual growth model. Experimental conditions and results of Gorsky (1980), Paffenhöfer (1976), Nin (1997), Alldredge (1981), King et al. (1980), Gorsky et al. (1987), and Fenaux (1985) are available to study (1) the influence of the food level on individual trunk length (TL); (2) the influence of temperature (T) on TL and generation time; (3) the influence of food quality on TL; (4) the influence of TL on filtration rate; (5) the influence of T and TL on respiration; (6) the influence of T and TL on excretion; and (7) the influence of T and TL on house production rate (see Table 9). Each of the 36 experiments in Table 9 is characterized by a set of 5 experimental conditions $\left(\mathrm{V}, \mathrm{F}_{\mathrm{C}}, \mathrm{F}_{\mathrm{N}}, \mathrm{T}\right.$, and $\left.\mathrm{E}\right)$ often derived from the source paper. Table 2 provides the values for all parameters of the model.
Influence of food level on trunk length

Expts 1 to 4 in Table 9 analyse the influence of the food level on TL. The primary goal of Gorsky (1980) was to determine the minimum food level required to allow positive growth and maturation of gonads. Results of these experiments are also presented by Gorsky \& Palazzoli (1989). Seawater filtered by $50 \mu \mathrm{m}$, originating from the Bay of Villefranche (French Mediterranean coast), was used for the cultures. In the 4 bottles containing 11 of seawater each, 10, 20, 50, and 200 individuals (selected just after the shift of the tail) were cultured. Since the growth of only 1 individual is simulated by the model, the volume of seawater per individual varies accordingly ( $\mathrm{V}$, Table 9). The original units of the food level used by Gorsky (1980) are ' $\mu \mathrm{m}^{3}$ food particles ind..$^{-1} \mathrm{~d}^{-1}$, which need to be transformed into carbon equivalents. This is done by using a conversion factor of $200 \mu \mathrm{gC} \mathrm{mm}^{-3}$ proposed by Mullin et al. (1966) for phytoplankton. Since the food supplied each day by Gorsky (1980) consisted of a mixture of phytoplankton species, we apply this factor to estimate the carbon weight of the food $\left(\mathrm{F}_{\mathrm{C}}\right.$, Table 9). From Expts 1 to 4 , it must be noted that both $\mathrm{V}$ and $\mathrm{F}_{\mathrm{C}}$ decrease, but that food concentration $\mathrm{F}_{\mathrm{C}}: \mathrm{V}$ remains constant (Table 9). The nitrogen weight of the food $\left(\mathrm{F}_{\mathrm{N}}\right)$ is also required to implement the model, but it cannot be estimated from the source paper. The Redfield C:N ratio of $5.68 \mu \mathrm{gC} \mu \mathrm{gN}^{-1}$ is applied to compute $\mathrm{F}_{\mathrm{N}}$. We thus assume that healthy phytoplankton was supplied in the cultures. The temperature $(\mathrm{T})$ is kept constant at $23^{\circ} \mathrm{C}$ during the experiments, and we consider that all food particles could efficiently be retained by the pharyngeal filter ( $\mathrm{E}=1$; Table 9$)$.

The results of the simulations are shown in Fig. 8. As observed in the cultures, generation time increases with decreasing food levels. Observed and simulated maximum TL remain constant however (ca. $750 \mu \mathrm{m}$ ). When simulating Expt 4 with the model, the individual was not able to reach threshold $\mathrm{TL}_{\mathrm{RG}}$. This indicates that the food quantity of $1.3 \mu \mathrm{gC}$ supplied each day was not enough to trigger the release of gametes. It is similar to the conclusions of Gorsky (1980) and Gorsky \& Palazzoli (1989) that the food level used during Expt $3\left(26 \times 10^{6} \mu^{3}\right.$ food particles ind..$^{-1} \mathrm{~d}^{-1}$, which corresponds to $5.2 \mu \mathrm{gC}$ ind..$^{-1}$ $\mathrm{d}^{-1}$ in the present study) was the minimum required to induce the release of gametes.

\section{Influence of temperature on trunk length and generation time}

The experimental data sets originated from Gorsky (1980) and Paffenhöfer (1976). Simulations corresponding to those of Gorsky (1980) use Expts 5 to 7 as 


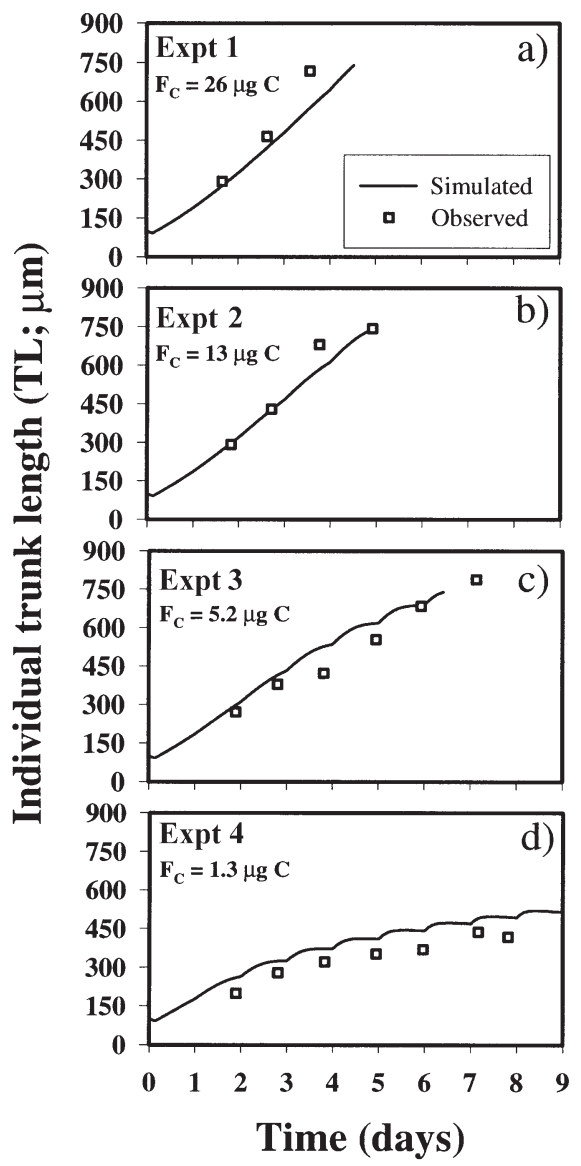

Fig. 8. Oikopleura dioica. Comparison between experimental observations and model simulations: influence of food level on individual trunk length. Experimental conditions are listed in Table 9

experimental conditions (Table 9), where only the temperature $\mathrm{T}$ varies $\left(23,20\right.$, and $13^{\circ} \mathrm{C}$, respectively). Similar conversion factors (volume of food particles to carbon, and C:N ratio; see above) were used to estimate $\mathrm{F}_{\mathrm{C}}$ and $\mathrm{F}_{\mathrm{N}}$. In these experiments, food concentration was much higher $\left(\mathrm{F}_{\mathrm{C}}: \mathrm{V}=650 \mu \mathrm{gC} \mathrm{l}^{-1}\right)$. Increasing the food concentration is a good strategy to obtain saturation of ingestion, since $F_{C} \gg k i$, and thus to focus on the effect of temperature on growth only. The results of the 3 simulations are shown in Fig. 9a-c. When temperature decreases, generation time and maximum trunk length $\mathrm{TL}_{\mathrm{RG}}$ increase. Although these characteristics are well reproduced by the model, it is clear that the model overestimates generation time and threshold $\mathrm{TL}_{\mathrm{RG}}$ in Expt 7 . This may indicate that either the slope atl (Table 2) used in Eqs. (19) \& (20) is underestimated, or that the life cycle of the cultured individuals (10 individuals in 0.4 l) was not yet completely finished, as discussed by Gorsky (1980).

Using seawater from the North Sea filtered through a $180 \mu \mathrm{m}$ mesh, Paffenhöfer (1976) measured the gen-
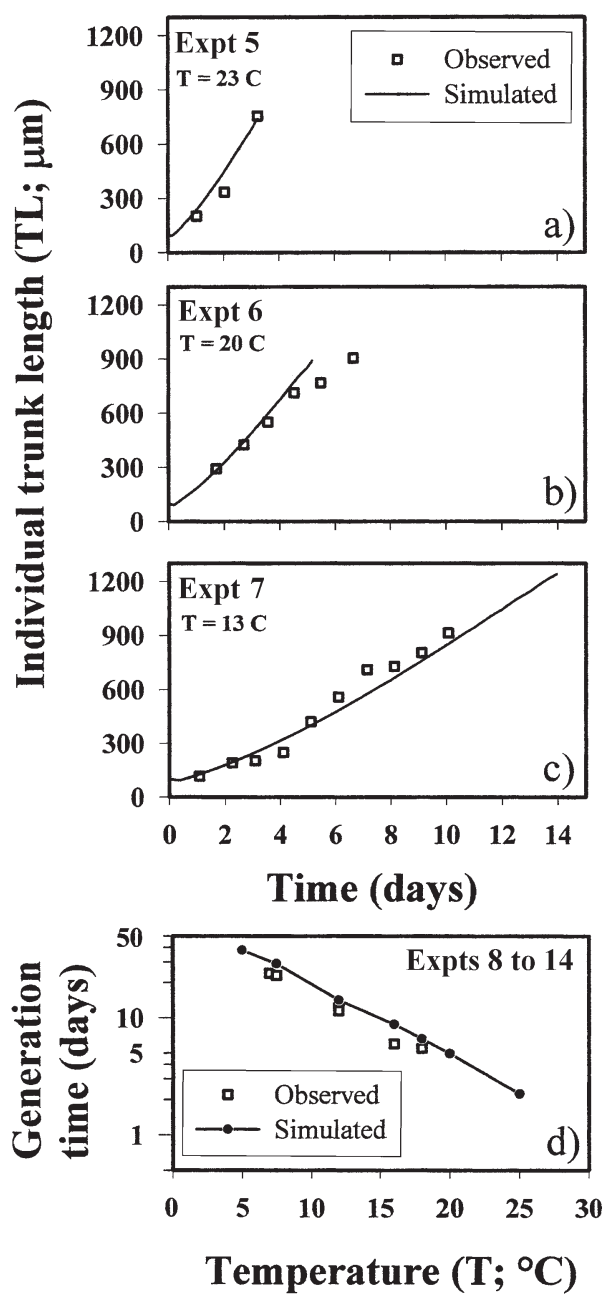

Fig. 9. Oikopleura dioica. Comparison between experimental observations and model simulations: influence of temperature on individual trunk length. Experimental conditions are listed in Table 9

eration time of Oikopleura dioica cultured under various conditions of temperature (from 7.5 to $18^{\circ} \mathrm{C}$ ). These data provide a good opportunity to test the behaviour of the present model, but many uncertainties exist on the conditions $\mathrm{F}_{\mathrm{C}}$ and $\mathrm{F}_{\mathrm{N}}$ to apply in the model. From the chlorophyll $a(\mathrm{chl} a)$ concentrations given by Paffenhöfer (1976), we estimate $\mathrm{F}_{\mathrm{C}}$ by using a POC:chl a ratio of $400 \mu \mathrm{gC}(\mu \mathrm{g} \mathrm{chl} \mathrm{a})^{-1}$. The utilisation of these data is complicated by the fact that the exact number of individuals in the cultures is unknown. These uncertainties would be of less importance if the food levels were saturating. We cannot affirm it, but we assume it is true, given the large quantities of carbon present in the food, as deduced from the above approximations.

The range of temperature used by Paffenhöfer (1976) was analysed using Expts 9 to 12, characterised by temperatures of $7.5,12,16$, and $18^{\circ} \mathrm{C}$, respectively. Since Oikopleura dioica is a species with worldwide 
distribution, it is interesting to extend the range of temperatures tested with the model. The effect of temperatures as low as $5^{\circ} \mathrm{C}$ (Expt 8) and as high as 20 and $25^{\circ} \mathrm{C}$ (Expts 13 and 14, respectively) on the generation time were thus analysed. Results of the 7 simulations corresponding to Expts 8 to 14 and Paffenhöfer's data are presented in Fig. 9d. The simulated generation times do not differ significantly from those observed by Paffenhöfer (1976). Given the very large range of temperatures tested $\left(5\right.$ to $\left.25^{\circ} \mathrm{C}\right)$, the simulated generation times may vary between approximately 2 and $40 \mathrm{~d}$.

Influence of food quality (C:N ratio) on trunk length

The influence of the elemental composition of substrates assimilated by bacteria or ingested by zooplankton, and the consequences on the overall structure of food webs, are debated in the recent literature (e.g. Urabe et al. 1995, Brussaard \& Riegman 1998, Touratier et al. 2001). The sole data available on this topic for appendicularians are those measured by Nin (1997) in G. Gorsky's laboratory at Villefranche sur Mer. Twenty Oikopleura dioica individuals cultured in a bottle filled with 21 of filtered seawater were fed with the small flagellate Isochrysis galbana cultured either under nitrate unstarved or starved conditions. Expts 15 and 16 (Table 9) are designed to simulate the results of Nin (1997). The food quantity $F_{C}$ was estimated using a specific conversion factor of $346 \mu \mathrm{gC} \mathrm{mm}{ }^{-3}$ provided by Gorsky (1980) for I. galbana. Surprisingly, the food C:N ratios for both starved and unstarved I. galbana are not available for these experiments. Consequently, for nitrate unstarved I. galbana we assume a C:N ratio of $6.37 \mu \mathrm{gC} \mu \mathrm{gN}^{-1}$, as recommended by Gorsky (1980). For nitrate starved cells, we assume that a $\mathrm{C}: \mathrm{N}$ ratio of $10 \mu \mathrm{gC} \mu \mathrm{gN}^{-1}$ is an appropriate choice. The food quantities $F_{N}$ for Expts 15 and 16 were computed from $F_{C}$ and these ratios (Table 9).

Simulated results are compared to the observations in Fig. 10. The data of Nin (1997) show that when food quality decreases (i.e. increasing $\mathrm{C}: \mathrm{N}$ ratio), the generation time increases and $\mathrm{TL}_{\mathrm{RG}}$ is lowered. The model predicts that the generation time increases in response to a poor quality of the food, but unrealistic outputs are generally obtained: $\mathrm{TL}_{\mathrm{RG}}$ remains constant and the predicted generation times are much longer than observed. To improve the overall quality of the simulated results, we changed the value of the 2 parameters a and ki in the model (Table 2) to be more representative of the specific prey (Isochrysis galbana). The experimental work of Acuña \& Kiefer (2000) suggests that values of $\mathrm{a}=49.51 \mathrm{pgC}^{0.25} \mathrm{~d}^{-1}$ and $\mathrm{ki}=38.9 \mathrm{\mu gCl}^{-1}$ could be more appropriate to simulate the influence of this alga on growth of Oikopleura dioica. Better results

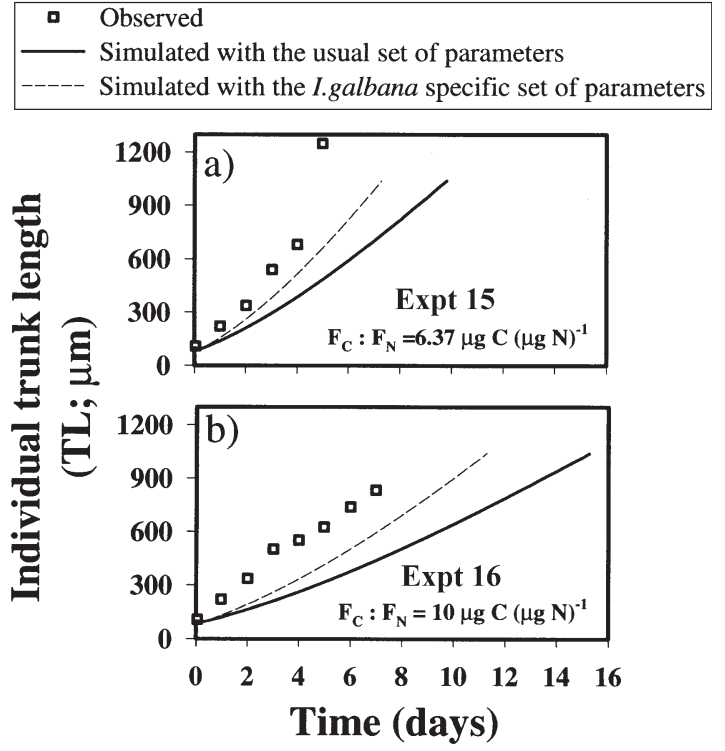

Fig. 10. Oikopleura dioica. Comparison between experimental observations and model simulations: influence of food quality ( $\mathrm{C}: \mathrm{N}$ ratio) on individual trunk length. Experimental conditions are listed in Table 9

are obtained with the model using this specific set of parameters (Fig. 10), but the difference remains important. Concerning the generation time, it must be noted, however, that Nin's data (Fig. 10a) are not always coherent with those of Paffenhöfer (1976): Fig. 9d shows that the generation time at $17^{\circ} \mathrm{C}$ (i.e. the temperature of Nin's experiments) should be 8 or $9 \mathrm{~d}$ instead of ca. $5 \mathrm{~d}$ as in Fig. 10a. The reason for such a disagreement between the 2 studies is unknown.

\section{Influence of the trunk length on the filtration rate}

The data sets of Alldredge (1981), King et al. (1980), Gorsky (1980), and Paffenhöfer (1976) were used to test the response of the present model to the filtration rate (Expts 17 to 20 in Table 9). Only the regression curves available from the original papers instead of the data themselves are presented here.

The in situ filtration rates of Oikopleura dioica were estimated by Alldredge (1981) in the surface waters of the Gulf of California during July 1979. The volume of the feeding chamber containing $1 O$. dioica was 0.1251 ( $\mathrm{V}$ of Expt 17 in Table 9). The averaged food concentration (POC) during the experiments was $120 \mathrm{\mu gC} \mathrm{l}^{-1}$, but according to the author a mean of $83.5 \%$ passed through the incurrent filters of the house (see Alldredge 1981 for details). The food concentration available for growth was thus $100.2 \mathrm{\mu gC} \mathrm{l}^{-1}$, which translates to $\mathrm{F}_{\mathrm{C}}=12.5 \mu \mathrm{gC}$ (see Table 9). The quantity $\mathrm{F}_{\mathrm{N}}$ 


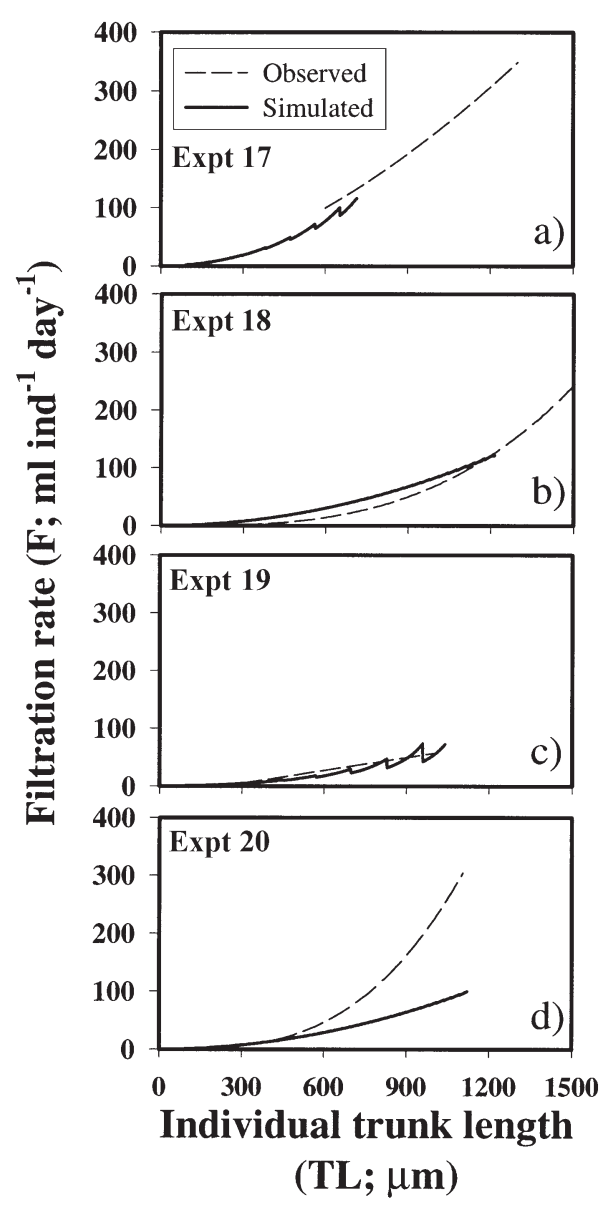

Fig. 11. Oikopleura dioica. Comparison between experimental observations and model simulations: influence of individual trunk length on filtration rate. Experimental conditions are listed in Table 9

was computed assuming that the $\mathrm{C}: \mathrm{N}$ Redfield ratio is representative of the available food. The average temperature during the experiments was $23.5^{\circ} \mathrm{C}$. The regression curve determined by Alldredge (1981) and the simulated results are presented in Fig. 11a. It must be noted, however, that in the experiments conducted by Alice Alldredge, several individuals of different sizes were enclosed separately in the chamber for the duration of the measurement only. The life history of these individuals is thus completely unknown, whereas the model simulates the development of an individual whose life history is completely known. The trunk length of individuals used by Alldredge (1981) was generally larger (600 to $1300 \mu \mathrm{m}$ ) than that computed with the model $(<715 \mu \mathrm{m})$. Among the factors analysed above (food level, temperature, and food quality), only the temperature could explain the difference, since $\mathrm{T}$ and $\mathrm{TL}$ are inversely correlated (see 'Influence of temperature on trunk length and generation time', and Fig. 9a-c). From this, we suspect that the life history of the individuals used by Alldredge (1981) could have been marked by cold periods. Interestingly, the regression curve of Alldredge (1981) is in continuity with that computed by the model, which indicates that the simulated filtration rates could be realistic for small-sized individuals.

One objective of King et al. (1980) was to estimate the filtration rate of Oikopleura dioica when it was fed with natural assemblages of free-living bacteria at Saanich Inlet, Canada. We assumed that the volume of $10 \mu \mathrm{m}$ filtered seawater placed in the bottle was $1 \mathrm{l}$; this information is not given by King et al. (1980). The mean bacterial biomass reached $52.5 \mu \mathrm{gC}^{-1}$, and thus $\mathrm{F}_{\mathrm{C}}=52.5 \mu \mathrm{gC}$ (see Expt 18 in Table 9). $\mathrm{F}_{\mathrm{N}}$ was estimated from $\mathrm{F}_{\mathrm{C}}$ using a bacterial $\mathrm{C}: \mathrm{N}$ ratio of $4 \mu \mathrm{gC}$ $\mu \mathrm{gN}^{-1}$ (Lancelot \& Billen 1985). The temperature during the experiments was maintained at $13.5^{\circ} \mathrm{C}$. The capture efficiency $\mathrm{E}$ of the pharyngeal filter is roughly estimated at 0.2 (Table 9) from the particle size retention spectra proposed by Acuña et al. (1996) for O. vanhoeffeni, considering that the size of bacterial cells ranges from 0.2 to $2 \mu \mathrm{m}$ (Painting 1989). As previously, the history of the individuals is unknown, but the simulated results are coherent with the observations (Fig. 11b).

Gorsky (1980), using $50 \mu \mathrm{m}$ filtered seawater from the Bay of Villefranche sur Mer, also provided estimates of the filtration rates for Oikopleura dioica, as represented by the linear regression in Fig. 11c. Using the experimental conditions of Expt 19 (Table 9), the simulated results are in the range of the experimental data.

Finally, the filtration rates estimated by Paffenhöfer (1976) were simulated using the conditions of Expt 20 (Table 9) and seawater cultures of $4 \mathrm{l}$. We assumed that 4 individuals (the exact number is unknown) were used in each bottle, i.e. $\mathrm{V}=1 \mathrm{l}$. The factor of Mullin et al. (1966) previously used to convert the volume of food particles into carbon equivalents was also applied to the original data, and $\mathrm{F}_{\mathrm{C}}=53.92 \mu \mathrm{gC}$ (Table 9). $\mathrm{F}_{\mathrm{N}}$ was deduced from $\mathrm{F}_{\mathrm{C}}$ using the Redfield $\mathrm{C}: \mathrm{N}$ ratio. The temperature was $13^{\circ} \mathrm{C}$ and $\mathrm{E}$ was set to 1 . The difference between the observed and the simulated rates is obvious, and it increases with body size. We suspect, however, that the present model is more realistic than Paffenhöfer's data, since (1) the results of the present model are coherent with 3 other independent data sets (Fig. 11a-c); (2) King et al. (1980) and Gorsky (1980) already pointed out the overestimated filtration rates obtained by Paffenhöfer (1976), especially because the number of individuals present in the cultures could have been underestimated; and (3) it is unnatural that the maximum filtration rates obtained by Alldredge (1981) and Paffenhöfer (1976) should be similar (compare Fig. 11a,d) considering a difference in temperature of $10.5^{\circ} \mathrm{C}$ between the 2 experiments (Table 9). 
Influence of temperature and trunk length on respiration rate

Respiration of Oikopleura dioica was analysed by Gorsky et al. (1987). The animals were first maintained in culture, and individuals of various sizes were introduced into beakers of 0.251 containing $30 \mu \mathrm{m}$ filtered seawater for 4 to $8 \mathrm{~h}$ to determine their respiration rates. A volume of food particles equivalent to $70 \mu \mathrm{gC}$ $\mathrm{l}^{-1}$ (conversion factor of Mullin et al. 1966) was added to the medium as soon as the individuals were incubated. This food concentration corresponds to $\mathrm{F}_{\mathrm{C}}=$ $17.5 \mu \mathrm{gC}$, and $\mathrm{F}_{\mathrm{N}}$ was computed using the Redfield $\mathrm{C}: \mathrm{N}$ ratio. E was set to 1 . Temperatures differed among the 3 experiments $\left(15,20\right.$ and $24^{\circ} \mathrm{C}$ for Expts 21 to 23 in Table 9, respectively). In the model, the respiration rate $\left(R_{C}\right)$ is computed in terms of carbon. To compare them to the experimental data of Gorsky et al. (1987), the simulated results were converted into oxygen units using a respiratory quotient $\left(\mathrm{CO}_{2}: \mathrm{O}_{2}\right)$ of 0.87 , as calculated by Gorsky (1980). Results of the simulation are shown in Fig. 12. The respiration rates increase with both TL and T, 2 characteristics that are well reproduced with the model. For $\mathrm{T} \geq 20^{\circ} \mathrm{C}$, some experimental points (where TL is maximum) could not be resolved with the model. This could be due to the experimental procedure adopted by Gorsky et al.

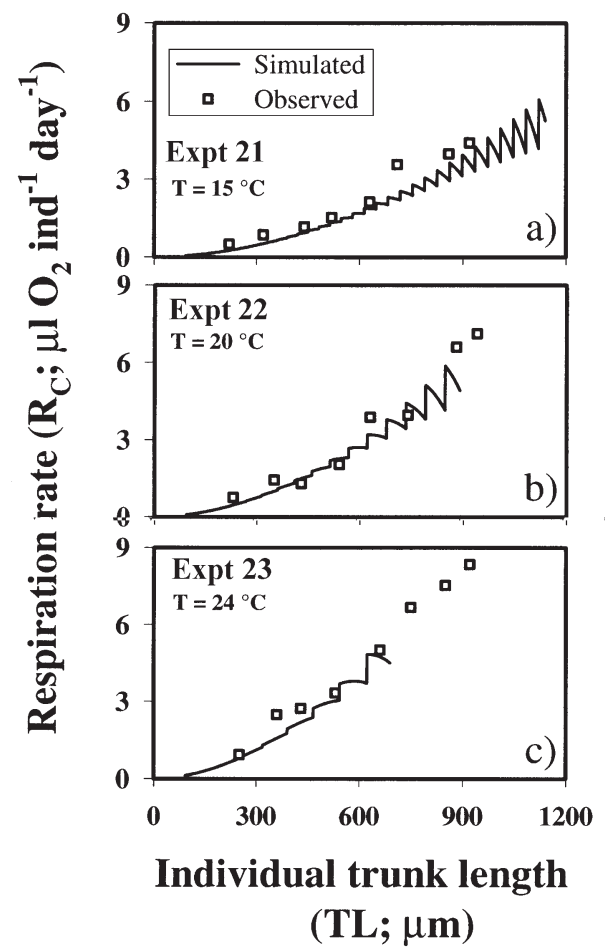

Fig. 12. Oikopleura dioica. Comparison between experimental observations and model simulations: influence of temperature and individual trunk length on respiration rate. Experimental conditions are listed in Table 9
(1987) that does not consider the life history of individuals prior to the experiments. The oscillations in the respiration rate result from the food level that becomes more and more limiting with the increase of the individual weight.

Influence of temperature and trunk length on excretion rate

Another goal of the Gorsky et al. (1987) study was to measure excretion rates using animals of different sizes, and at various temperatures. The overall experimental procedure followed that adopted to determine respiration rates (see details in Gorsky et al. 1987). However, the volume of the beakers was smaller (0.1 1), and $\mathrm{F}_{\mathrm{C}}$ was consequently reduced to $7 \mu \mathrm{gC}$ (see Expts 24 to 26 in Table 9). The outputs of the model and the experimental data are compared in Fig. 13. Excretion rate also increased with both TL and T. This is reproduced by the model, but simulated results corresponding to the highest temperature are slightly overestimated. The amplitude of the oscillations increases with $\mathrm{TL}$, especially when the temperature is low.

Influence of temperature and trunk length on house production rate

During appendicularian bloom events, abandoned houses may represent a large fraction of the total carbon export (Fortier et al. 1994). This effect is accentuated by the high potential of houses to aggregate around suspended particles. It is therefore interesting to evaluate the house production rate of appendicularians, which is largely affected by temperature and individual trunk length. The experimental studies of Fenaux (1985) and Gorsky (1980) on Oikopleura dioica provide a nice opportunity to test the ability of the present model to approach such measurements.

Using filtered seawater originating from the Bay of Villefranche sur Mer, Fenaux (1985) measured the house production rate of individuals maintained at 5 temperatures $\left(14,16,18,20\right.$ and $\left.22^{\circ} \mathrm{C}\right)$ whose trunk length ranged from 500 to $600 \mu \mathrm{m}$ (see Expts 29 to 33 in Table 9). Prior to the measurements, the individuals were first cultured at $18^{\circ} \mathrm{C}$ and then adapted to the experimental temperature during a period of $24 \mathrm{~h}$. Fenaux (1985) used beakers of 0.35 l, with 10 individuals per beaker ( $\mathrm{V}=0.035 \mathrm{l}$, Table 9 ). Neither the quantity of food nor its quality were specified by Fenaux (1985). We hypothesize that (1) food level was at saturation $\left(\mathrm{F}_{\mathrm{C}}=26 \mu \mathrm{gC}\right.$; food concentration is thus $742.8 \mu \mathrm{gC} \mathrm{l}^{-1}$, Table 9); (2) the food supplied each day into the beakers was of high quality (i.e. the Redfield 


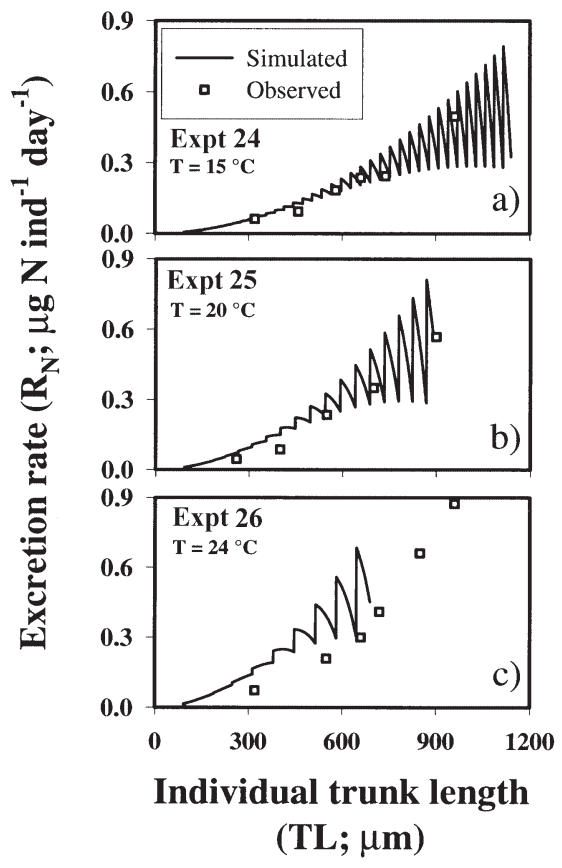

Fig. 13. Oikopleura dioica. Comparison between experimental observations and model simulations: influence of temperature and individual trunk length on excretion rate. Experimental conditions are listed in Table 9

C:N ratio was used to calculate $\mathrm{F}_{\mathrm{N}}$ from $\mathrm{F}_{\mathrm{C}}$, Table 9); and (3) all food particles were efficiently captured by the pharyngeal filtering apparatus (i.e. $E=1$ ). In the model, as during the experiments, house production rates were computed when individuals had trunk lengths of 500 to $600 \mu \mathrm{m}$. Three additional temperatures are tested with the model $\left(5,10\right.$ and $25^{\circ} \mathrm{C}$; Expts 27, 28, and 34 of Table 9). Although they are slight overestimates, the simulated results are in agreement with the observations (Fig. 14a). Clearly, house production rate increases with temperature. Concerning the range of temperature $\left(14\right.$ to $\left.22^{\circ} \mathrm{C}\right)$ experimentally tested by Fenaux (1985), one of his conclusions was that the relationship between house production rate and temperature could be adequately fitted by a straight line, but that it should actually be sigmoid. The simulated curve (Fig. 14a) is neither linear nor sigmoid, but exponential, which is a direct consequence of the parameterisation adopted to represent the influence of temperature $\left(Q_{10}\right)$ on processes of the model (see above).

Individual trunk length also influences the duration of house functioning, as shown by Gorsky (1980). Two experiments (Expts 35 and 36 of Table 9) were designed to evaluate the duration of house functioning during the life time of an individual cultured at either $13^{\circ} \mathrm{C}$, or $20^{\circ} \mathrm{C}$. The volume $\mathrm{V}$ was set to $1 \mathrm{l}$, and the food concentration used in the model, $\mathrm{F}_{\mathrm{C}}: \mathrm{V}=136.1$ $\mu \mathrm{gC} 1^{-1}$, was the same as in Gorsky (1980). In fact, approximately $10^{4}$ cells ml-1 of Isochrysis galbana containing in average $1.310^{-5} \mathrm{ugC} \mathrm{cell}^{-1}$ were added each day into the bottles filled with filtered $(0.45 \mu \mathrm{m})$ seawater (Gorsky 1980). The observations and the simulated results are compared in Fig. 14b \& c. The duration of house functioning increases with individual trunk length, and decreases with increasing temperature. The simulation with the usual set of parameters gave poor results. When the I. galbana-specific set of parameters a and ki (see 'Influence of food quality [C:N ratio] on trunk length') is used, better results are obtained with the model, but they are still far from the observations.

The deployment of a new house takes only a few minutes (Alldredge 1981, Fenaux 1985), the relationship between the duration of the house functioning (DHF) and the house production (HPR) is obvious (HPR $=24 / \mathrm{DHF})$. This relationship was used to compare the experimental results of Gorsky (1980; Fig. 14b,c) with those of Fenaux (1985; Fig. 14a). At $\mathrm{T}=13^{\circ} \mathrm{C}$ and $\mathrm{TL}=$
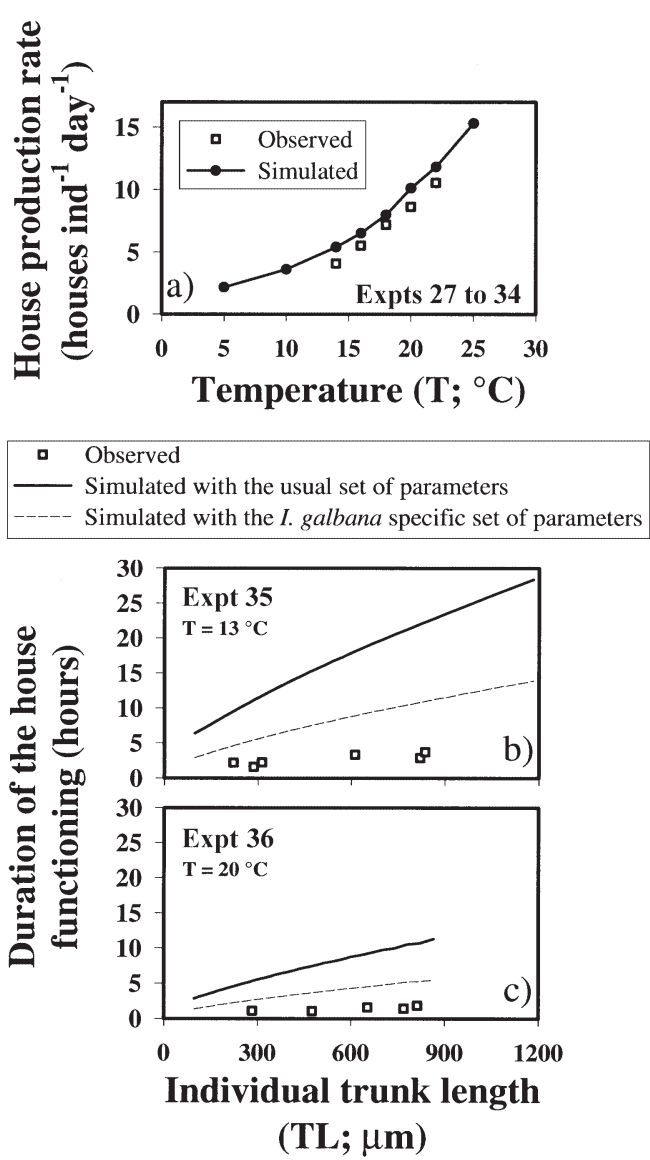

Fig. 14. Oikopleura dioica. Comparison between experimental observations and model simulations: influence of temperature and individual trunk length on house production rate. Experimental conditions are listed in Table 9 
$550 \mu \mathrm{m}$ (i.e. the mean size of the individuals considered by Fenaux 1985), the duration of the house functioning is ca. $2.5 \mathrm{~h}$ (Fig. 14b), for a house production rate of ca. 9.6 houses ind. ${ }^{-1} \mathrm{~d}^{-1}$. At $\mathrm{T}=20^{\circ} \mathrm{C}$ and $\mathrm{TL}=$ $550 \mu \mathrm{m}$ (Fig. 14c), the appendicularian house lasts only $1 \mathrm{~h}$, for a house production rate of 24 houses ind..$^{-1} \mathrm{~d}^{-1}$. When these rates are reported on Fig. 14a, the difference between the 2 data sets is striking. The discrepancy noted between these observations could partly explain the low quality of the simulated results which appear in Fig. 14b,c.

\section{DISCUSSION AND CONCLUSIONS}

The large spectrum of simulated situations in stable conditions provides a good validation of the model, as modelled growth usually agreed with experimental data. This concerns the influence of food quantity and temperature on generation time and trunk length, influence of temperature and trunk length on respiration and excretion, and on filtration and house production rates.

Nevertheless, 3 main inconsistencies appear between model output and experimental observations: (1) the influence of food quality using the data of Nin (1997), (2) the filtration rate using the data set of Paffenhöfer (1976), and (3) the house production rates using the observations of Gorsky (1980; see Figs. 10, $11 d \& 14 b, c)$. As mentioned in 'Influence of the trunk length on the filtration rate', the filtration rate measured by Paffenhöfer (1976) differs from the other data sets (i.e. Gorsky 1980, King et al. 1980, Alldredge 1981), and the inconsistency may originate from the data, and not from the model. The same applies to the house production rates measured by Gorsky (1980) and Fenaux (1985). The discrepancy between model output and the data of Nin (1997) concerning the influence of food quality on individual growth cannot be explained without additional experiments. The Isochrysis galbana-specific set of parameters (Fig. 10) improved the simulated results, but they are still far from the experimental observations.

Among the 36 experiments listed in Table 9, there is none where all 5 conditions $\left(\mathrm{V}, \mathrm{F}_{\mathrm{C}}, \mathrm{F}_{\mathrm{N}}, \mathrm{T}\right.$, and $\left.\mathrm{E}\right)$ are obtained directly from a referenced paper. For instance, the volume of seawater or the number of individuals in the culture is sometimes unknown, as in King et al. (1980) and Paffenhöfer (1976), respectively. In most cases, the quantity or concentration of food was determined, but the units (volume of food particles or chl a) often necessitate the utilisation of approximate conversion factors in order to obtain the equivalent in terms of carbon, as in Paffenhöfer (1976), Gorsky (1980), and Gorsky et al. (1987). When using natural seawater to feed appendicularians during their experiments, scientists should determine the concentration of small particles (colloids, viruses, bacteria, and picoplankton) to correctly evaluate the ration of available food. This could help to understand the role of these organisms in their experiment. The $\mathrm{C}: \mathrm{N}$ ratio of the food is never specified in the experiments, even when the aim of the study was to test the influence of food quality on individual growth (Nin 1997). As a first approximation, the C:N Redfield ratio was widely used to estimate $F_{N}$ from $F_{C}$. The life history of an organism should be accurately known, since it determines a large part of the physiological response during an experiment. As discussed previously, the results obtained by Alldredge (1981) and Gorsky et al. (1987) were affected by the animals' life histories.

For modelling studies, as well as for the overall understanding and interpretation of the physiological responses of individuals during experiments, we recommend a rigorous description of the following experimental conditions: (1) volume of seawater used; (2) exact number of individuals per incubation; (3) food quantity in terms of carbon, nitrogen, and eventually phosphorus; (4) temperature; (5) life history of the experimental organisms; and (6) size spectrum of food particles supplied to the culture, to estimate the animals' capture efficiency. Moreover, given the large range of values on the assimilation efficiencies (AE) of appendicularians published, it would be useful to determine the AE for different prey types.

Especially in the case of P-limited ecosystems such as the Mediterranean Sea (Thingstad \& Rassoulzadegan 1995, Thingstad et al. 1998) we strongly recommend to measure the appendicularian compartments (body, house) and processes (ingestion, assimilation, excretion) in terms of phosphorus. This is for the following reasons: (1) there is practically no estimate of $\mathrm{P}$ in the literature on appendicularians; (2) the so-called 'growth rate hypothesis' (Sterner 1995, Elser et al. 1996) states that rapidly growing heterotrophs (e.g. appendicularians) have a higher $\mathrm{P}$ content (mainly due to ribosomal RNA) than slow-growing organisms (see also Main et al. 1997, Vrede et al. 1999); and (3) heterotrophs with higher P content could favor or accentuate $\mathrm{P}$ limitation in ecosystems by sequestering $\mathrm{P}$ in their biomass (e.g. Hassett et al. 1997, Touratier et al. 2001).

The overall effect of food quality (elemental composition, size of particles, and protein or lipid content) on growth should be further explored both in situ and in the laboratory, and at the individual, population and ecosystem levels.

The experiments conducted during the EC's EURAPP project provide further opportunities to test the structure and behaviour of the present model. The next step 
will be to consider experiments with fluctuating food quantity and quality, temperature, and size of nutritive particles, to simulate the natural variability of these parameters. Another step will be to model the population dynamics of Oikopleura dioica and other representative appendicularian species to analyse competition among appendicularian species, and between appendicularians and copepods, for instance (see the model proposed by Carlotti \& Hirche 1997). However, the high number of state variables (18) in the present individual growth model is a handicap for reaching this level of complexity. Some aggregations of the state variables should be tested in order to reduce their number, speed up the model implementation, and consequently simulate realistically the dynamics of a population.

Acknowledgements. This work was supported by EURAPP, a project funded by the European Community under contract MAS3-CT98-0161. We are very grateful to the scientists involved in this project, especially for the numerous and stimulating discussions on the topic. Special thanks also to D. Deibel and J. L. Acuña, who organised the session on the Ecology of Pelagic Gelatinous Zooplankton at the ASLO meeting of Albuquerque during February 2001. We also thank the 4 anonymous referees for their most helpful comments.

\section{LITERATURE CITED}

Acuña JL, Anadón R (1992) Appendicularian assemblages in a shelf area and their relationship with temperature. J Plankton Res 14:1233-1250

Acuña JL, Kiefer M (2000) Functional response of the appendicularian Oikopleura dioica. Limnol Oceanogr 45:608-618

Acuña JL, Bedo AW, Harris RP, Anadón R (1995) The seasonal succession of appendicularians (tunicata: appendicularia) off Plymouth. J Mar Biol Assoc UK 75:755-758

Acuña JL, Deibel D, Morris CC (1996) Particle capture mechanism of the pelagic tunicate Oikopleura vanhoeffeni. Limnol Oceanogr 41:1800-1814

Acuña JL, Deibel D, Bochdansky AB, Hatfield E (1999) In situ ingestion rates of appendicularian tunicates in the Northeast Water Polynya (NE Greenland). Mar Ecol Prog Ser 186:149-160

Alldredge AL (1976) Discarded appendicularian houses as sources of food, surface habitats, and particulate organic matter in planktonic environments. Limnol Oceanogr 21: $14-23$

Alldredge AL (1981) The impact of appendicularian grazing on natural food concentration in situ. Limnol Oceanogr 26: $247-257$

Azam F, Fenchel T, Gray JS, Meyer-Reil LA, Thingstad F (1983) The ecological role of water-column microbes in the sea. Mar Ecol Prog Ser 10:257-263

Bedo AW, Acuña JL, Robins D, Harris RP (1993) Grazing in the micron and the sub-micron particle size range: the case of Oikopleura dioica (Appendicularia). Bull Mar Sci 53:2-14

Bochdansky AB, Deibel D, Rivkin RB (1999) Absorption efficiencies and biochemical fractionation of assimilated compounds in the cold water appendicularian Oikopleura vanhoeffeni. Limnol Oceanogr 44:415-424
Brussaard CPD, Riegman R (1998) Influence of bacteria on phytoplankton cell mortality with phosphorus or nitrogen as the algal-growth-limiting nutrient. Aquat Microb Ecol 14:271-280

Carlotti F, Hirche HJ (1997) Growth and egg production of female Calanus finmarchicus: an individual-based physiological model and experimental validation. Mar Ecol Prog Ser 149:91-104

Deibel D (1985) Blooms of the pelagic tunicate, Dolioletta gegenbauri: are they associated with Gulf Stream frontal eddies? J Mar Res 43:211-236

Deibel D (1986) Feeding mechanism and house of the appendicularian Oikopleura vanhoeffeni. Mar Biol 93:429-436

Deibel D (1988) Filter feeding by Oikopleura vanhoeffeni: grazing impact on suspended particles in cold ocean waters. Mar Biol 99:177-186

Deibel D (1998) Feeding and metabolism of appendicularia. In: Bone Q (ed) The biology of pelagic tunicates. Oxford University Press, Oxford, p 139-149

Deibel D, Lee SH (1992) Retention efficiency of sub-micrometer particles by the pharyngeal filter of the pelagic tunicate Oikopleura vanhoeffeni. Mar Ecol Prog Ser 81:25-30

Deibel D, Powell CVL (1987) Ultrastructure of the pharyngeal filter of the appendicularian Oikopleura vanhoeffeni: implications for particle size selection and fluid mechanics. Mar Ecol Prog Ser 35:243-250

Deibel D, Turner JT (1985) Zooplankton feeding ecology: contents of fecal pellets of the appendicularian Oikopleura vanhoeffeni. Mar Ecol Prog Ser 27:67-78

Deibel D, Cavaletto JF, Riehl M, Gardner WS (1992) Lipid and lipid class content of the pelagic tunicate Oikopleura vanhoeffeni. Mar Ecol Prog Ser 88:297-302

Elser JJ, Dobberfuhl DR, MacKay NA, Schampel JH (1996) Organism size, life history, and N:P stoichiometry. BioScience 46:674-684

Fenaux R (1961) Existence d'un ordre cyclique d'abondance relative maximale chez les appendiculaires de surface (tuniciers pélagiques). CR Hebd Séances Acad Sci 253: 2271-2273

Fenaux R (1976) Premières données spécifiques sur les rapports poids/taille chez les appendiculaires en Méditerranée. Rapp Comm Int Mer Médit 23:67-69

Fenaux R (1985) Rhythm of secretion of oikopleurid's houses. Bull Mar Sci 37:498-503

Fenaux R (1986) The house of Oikopleura dioica (Tunicata, Appendicularia): structure and functions. Zoomorphology 106:224-231

Fenaux R (1998a) Anatomy and functional morphology of the appendicularia. In: Bone $\mathrm{Q}$ (ed) The biology of pelagic tunicates. Oxford University Press, Oxford, p 25-34

Fenaux R (1998b) Life history of the appendicularia. In: Bone $\mathrm{Q}$ (ed) The biology of pelagic tunicates. Oxford University Press, Oxford, p 151-159

Fenaux R, Gorsky G (1983) Cycle vital et croissance de l'appendiculaire Oikopleura longicauda. Ann Inst Océanogr 59:107-116

Fenaux R, Gorsky G (1985) Nouvelle technique d'élevage des appendiculaires. Rapp PV Réun Comm Int Explor Sci Mer Méditerr Monaco 29:291-292

Fenaux R, Bedo A, Gorsky G (1986) Premières données sur la dynamique d'une population d'Oikopleura dioica Fol, 1872 (Appendiculaire) en élevage. Can J Zool 64:1745-1749

Flood PR (1978) Filter characteristics of appendicularian food catching nets. Experientia 34:173-175

Flood PR (1981) On the ultrastructure of mucus. Biomed Res 2:49-53

Flood PR, Deibel D (1998) The appendicularian house. In: 
Bone Q (ed) The biology of pelagic tunicates. Oxford University Press, Oxford, p 106-124

Flood PR, Deibel D, Morris CC (1990) Visualization of the transparent, gelatinous house of the pelagic tunicate Oikopleura vanhoeffeni using sepia ink. Biol Bull (Woods Hole) 178:118-125

Flood PR, Deibel D, Morris CC (1992) Filtration of colloidal melanin from sea water by planktonic tunicates. Nature 355:630-632

Fortier L, Le Fèvre J, Legendre L (1994) Export of biogenic carbon to fish and to the deep ocean: the role of large planktonic microphages. J Plankton Res 16:809-839

Galt CP (1972) Development of Oikopleura dioica (Urochordata: Larvacea): ontogeny of behavior and of organ systems related to construction and use of the house. PhD thesis, University of Washington, Seattle

Gorsky G (1980) Optimisation des cultures d'appendiculaires. Approche du métabolisme de $O$. dioica. PhD thesis, Université Pierre et Marie Curie, Paris VI

Gorsky G, Fenaux R (1998) The role of appendicularia in marine food webs. In: Bone Q (ed) The biology of pelagic tunicates. Oxford University Press, Oxford, p 161-169

Gorsky G, Palazzoli I (1989) Aspects de la biologie de l'appendiculaire. Océanis 15:39-49

Gorsky G, Fisher NS, Fowler SW (1984) Biogenic debris from the pelagic tunicate, Oikopleura dioica, and its role in the vertical transport of a transuranium element. Estuar Coast Shelf Sci 18:13-23

Gorsky G, Palazzoli I, Fenaux R (1987) Influence of temperature changes on oxygen uptake and ammonia and phosphate excretion, in relation to body size and weight, in Oikopleura dioica (Appendicularia). Mar Biol 94:191-201

Gorsky G, Dallot S, Sardou J, Fenaux R, Carré C, Palazzoli I (1988) C and N composition of some northwestern Mediterranean zooplankton and micronekton species. J Exp Mar Biol Ecol 124:133-144

Gorsky G, Chrétiennot-Dinet MJ, Blanchot J, Palazzoli I (1999) Picoplankton and nanoplankton aggregation by appendicularians: fecal pellet contents of Megalocercus huxleyi in the equatorial Pacific. J Geophys Res 104: 3381-3390

Hansen PJ, Bjørnsen PK, Hansen BW (1997) Zooplankton grazing and growth: scaling within the $2-2000-\mu m$ body size range. Limnol Oceanogr 42:687-704

Hassett RP, Cardinale B, Stabler LB, Elser JJ (1997) Ecological stoichiometry of $\mathrm{N}$ and $\mathrm{P}$ in pelagic ecosystems: comparison of lakes and oceans with emphasis on the zooplankton-phytoplankton interaction. Limnol Oceanogr 42: 648-662

Hopcroft RR, Roff JC (1995) Zooplankton growth rates: extraordinary production by the larvacean Oikopleura dioica in tropical waters. J Plankton Res 17:205-220

King KR, Hollibaugh JT, Azam F (1980) Predator-prey interactions between the larvacean Oikopleura dioica and bacterioplankton in enclosed water columns. Mar Biol 56: 49-57

Körner WF (1952) Untersuchungen über die Gehäusebildung bei Appendicularien (Oikopleura dioica Fol). Z Morphol Oekol Tiere 41:1-53

Editorial responsibility: Otto Kinne (Editor), Oldendorf/Luhe, Germany
Lancelot C, Billen G (1985) Carbon-nitrogen relationships in nutrient metabolism of coastal marine ecosystems. Adv Aquat Microbiol 3:263-321

López-Urrutia A, Acuña JL (1999) Gut throughput dynamics in the appendicularian Oikopleura dioica. Mar Ecol Prog Ser 191:195-205

Main TM, Dobberfuhl DR, Elser JJ (1997) N:P stoichiometry and ontogeny of crustacean zooplankton: a test of the growth rate hypothesis. Limnol Oceanogr 42:1474-1478

Moloney CL, Field JG (1989) General allometric equations for rates of nutrient uptake, ingestion, and respiration in plankton organisms. Limnol Oceanogr 34:1290-1299

Morris CC, Deibel D (1993) Flow rate and particle concentration within the house of the pelagic tunicate Oikopleura vanhoeffeni. Mar Biol 115:445-452

Mullin MM, Sloan PR, Eppley RW (1966) Relationship between carbon content, cell volume and area in phytoplankton. Limnol Oceanogr 11:307-311

Nakamura Y, Suzuki K, Suzuki Sy, Hiromi J (1997) Production of Oikopleura dioica (Appendicularia) following a picoplankton 'bloom' in a eutrophic coastal area. J Plankton Res 19:113-124

Nin F (1997) Influence de la qualité alimentaire sur l'évolution d'une population d'appendiculaires (Oikopleura dioica). DEA thesis, Université Pierre et Marie Curie, Paris VI

Paffenhöfer GA (1976) On the biology of appendicularia of the southeastern North Sea. In: Persoone G, Jaspers E (eds) Proc 10th Eur Mar Biol Symp, Ostend, Belgium, Sept $17-23,1975,2: 437-455$

Painting SJ (1989) Bacterioplankton dynamics in the southern Benguela upwelling region. PhD thesis, University of Cape Town

Sterner R (1990) The ratio of nitrogen to phosphorus resupplied by herbivores: zooplankton and the algal competition arena. Am Nat 136:209-229

Sterner R (1995) Elemental stoichiometry of species in ecosystems. In: Jones CG, Lawton JH (eds) Linking species and ecosystems. Chapman \& Hall, New York, p 240-252

Thingstad TF, Rassoulzadegan F (1995) Nutrient limitations, microbial food webs, and 'biological C-pumps': suggested interactions in a P-limited Mediterranean. Mar Ecol Prog Ser 117:299-306

Thingstad TF, Zweifel UL, Rassoulzadegan F (1998) P limitation of heterotrophic bacteria and phytoplankton in the northwest Mediterranean. Limnol Oceanogr 43:88-94

Touratier F, Legendre L, Vézina A (1999) Model of copepod growth influenced by the food carbon:nitrogen ratio and concentration, under the hypothesis of strict homeostasis. J Plankton Res 21:1111-1132

Touratier F, Field JG, Moloney CL (2001) A stoichiometric model relating growth substrate quality ( $\mathrm{C}: \mathrm{N}: \mathrm{P}$ ratios) to $\mathrm{N}: \mathrm{P}$ ratios in the products of heterotrophic release and excretion. Ecol Model 139:265-291

Urabe J, Nakanishi M, Kawabata K (1995) Contribution of metazoan plankton to the cycling of nitrogen and phosphorus in Lake Biwa. Limnol Oceanogr 40:232-241

Vrede T, Anderson T, Hessen DO (1999) Phosphorus distribution in three crustacean zooplankton species. Limnol Oceanogr 44:225-229

Submitted: June 25, 2002; Accepted: October 22, 2002

Proofs received from author(s): January 23, 2003 